Article

\title{
Intermittent Hypoxic Conditioning Rescues Cognition and Mitochondrial Bioenergetic Profile in the Triple Transgenic Mouse Model of Alzheimer's Disease
}

\author{
Sónia C. Correia ${ }^{1,2,3, *(\mathbb{D})}$, Nuno J. Machado ${ }^{1}(\mathbb{D})$, Marco G. Alves ${ }^{4}\left(\mathbb{D}\right.$, Pedro F. Oliveira ${ }^{5}$ (D) \\ and Paula I. Moreira $1,2,6, * \mathbb{D}$
}

1 Center for Neuroscience and Cell Biology (CNC), University of Coimbra, 3004-504 Coimbra, Portugal; nihonmeru@yahoo.co.uk

2 Center for Innovative Biomedicine and Biotechnology (CIBB), University of Coimbra, 3004-504 Coimbra, Portugal

3 Institute for Interdisciplinary Research, University of Coimbra, 3030-789 Coimbra, Portugal

4 Unit for Multidisciplinary Research in Biomedicine (UMIB), Department of Anatomy, Institute of Biomedical Sciences Abel Salazar (ICBAS), University of Porto, 4050-313 Porto, Portugal; alvesmarc@gmail.com

5 QOPNA \& LAQV, Department of Chemistry, University of Aveiro, 3810-193 Aveiro, Portugal; p.foliveira@ua.pt

6 Laboratory of Physiology, Faculty of Medicine, University of Coimbra, 3000-548 Coimbra, Portugal

* Correspondence: sonia.s.correia84@gmail.com (S.C.C.); pimoreira@fmed.uc.pt (P.I.M.); Tel.: 351-239-820190 (S.C.C. \& P.I.M.)

check for updates

Citation: Correia, S.C.; Machado, N.J.; Alves, M.G.; Oliveira, P.F.; Moreira,

P.I. Intermittent Hypoxic

Conditioning Rescues Cognition and Mitochondrial Bioenergetic Profile in the Triple Transgenic Mouse Model of Alzheimer's Disease. Int. J. Mol. Sci. 2021, 22, 461. https://doi.org/ 10.3390/ijms22010461

Received: 20 December 2020 Accepted: 31 December 2020 Published: 5 January 2021

Publisher's Note: MDPI stays neutral with regard to jurisdictional clai$\mathrm{ms}$ in published maps and institutional affiliations.

Copyright: (C) 2021 by the authors. Licensee MDPI, Basel, Switzerland. This article is an open access article distributed under the terms and conditions of the Creative Commons Attribution (CC BY) license (https:// creativecommons.org/licenses/by/ $4.0 /)$.

\begin{abstract}
The lack of effective disease-modifying therapeutics to tackle Alzheimer's disease (AD) is unsettling considering the actual prevalence of this devastating neurodegenerative disorder worldwide. Intermittent hypoxic conditioning (IHC) is a powerful non-pharmacological procedure known to enhance brain resilience. In this context, the aim of the present study was to investigate the potential long-term protective impact of IHC against AD-related phenotype, putting a special focus on cognition and mitochondrial bioenergetics and dynamics. For this purpose, six-month-old male triple transgenic AD mice $(3 \times \mathrm{Tg}-\mathrm{AD})$ were submitted to an $\mathrm{IHC}$ protocol for two weeks and the behavioral assessment was performed at 8.5 months of age, while the sacrifice of mice occurred at nine months of age and their brains were removed for the remaining analyses. Interestingly, IHC was able to prevent anxiety-like behavior and memory and learning deficits and significantly reduced brain cortical levels of amyloid- $\beta$ (A $\beta)$ in $3 \times \mathrm{Tg}-\mathrm{AD}$ mice. Concerning brain energy metabolism, IHC caused a significant increase in brain cortical levels of glucose and a robust improvement of the mitochondrial bioenergetic profile in $3 \times \mathrm{Tg}$ - $\mathrm{AD}$ mice, as mirrored by the significant increase in mitochondrial membrane potential $(\triangle \Psi \mathrm{m})$ and respiratory control ratio (RCR). Notably, the improvement of mitochondrial bioenergetics seems to result from an adaptative coordination of the distinct but intertwined aspects of the mitochondrial quality control axis. Particularly, our results indicate that IHC favors mitochondrial fusion and promotes mitochondrial biogenesis and transport and mitophagy in the brain cortex of $3 \times \mathrm{Tg}$-AD mice. Lastly, IHC also induced a marked reduction in synaptosomal-associated protein $25 \mathrm{kDa}$ (SNAP-25) levels and a significant increase in both glutamate and GABA levels in the brain cortex of $3 \times \mathrm{Tg}-\mathrm{AD}$ mice, suggesting a remodeling of the synaptic microenvironment. Overall, these results demonstrate the effectiveness of the IHC paradigm in forestalling the $\mathrm{AD}$-related phenotype in the $3 \times \mathrm{Tg}-\mathrm{AD}$ mouse model, offering new insights to $\mathrm{AD}$ therapy and forcing a rethink concerning the potential value of non-pharmacological interventions in clinical practice.
\end{abstract}

Keywords: Alzheimer's disease; brain cortex; cognition; intermittent hypoxic conditioning; mitochondrial bioenergetics and dynamics; synaptic integrity; $3 \times$ Tg-AD mouse model 


\section{Introduction}

With a worldwide population that is aging at a rapid pace, the prevalence of $\mathrm{AD}$ is now reaching alarming proportions emerging as one of the major global epidemics of the 21st century [1]. Bereft of a cure, AD is currently the most common type of dementia, affecting more than 44 million people worldwide [2-4], this number being projected to triplicate by 2050. Within this scenario, AD represents a major frontier in medical research, a major challenge for the pharmaceutical industry, and a burden for society.

From a clinical perspective, AD has been conceptualized as a continuum that begins with a long asymptomatic or preclinical phase that typically progresses to dementia [5]. The clinical diagnosis of $\mathrm{AD}$ represents the end-stage of a decade-long silent disease process since the disruption of brain structure and function precede the discernible clinical manifestation of the disease by 20-30 years [6]. The cardinal symptoms of AD are an initial impairment in episodic memory that progresses continuously to a severe cognitive decline, and behavioral disturbances $[7,8]$. Neuropathologically, the AD signature is defined by the presence of extracellular deposition of $A \beta$ peptide in senile plaques and the intracellular accumulation of neurofibrillary tangles containing hyperphosphorylated tau protein [9]. Despite the limited knowledge regarding the molecular roots behind $\mathrm{AD}$, mitochondrial abnormalities have also been pinpointed as one of the earliest and strongest events during the pathological course of the disease [10].

More than 100 years after the first case report and the groundbreaking advances in understanding $\mathrm{AD}$ pathophysiology, the management of this complex disorder only provides symptomatic relief with no effective disease-modifying therapeutics able to halt the neurodegenerative processes before reaching a "point of no return". As a matter of fact, according to the Pharmaceutical Research and Manufacturers of America (PhRMA), between 1998 and 2017, 146 anti-AD drugs failed in clinical practice worldwide, and only four have been marketed successfully. In this sense, the successive failure of pharmacotherapy encourages the "hunt" for new alternative interventions directed to AD.

Over the last decades a growing interest on the potential therapeutic application of conditioning in the context of brain disorders has emerged [11-13]. Conditioning is an adaptive biological process activated through the exposure to a sub-threshold insult (e.g., hypoxia, physical exercise, temperature) able to confer resistance to a deleterious brain event [14,15]. In 2009, it was reported for the first time that IHC counteracts ADrelated cognitive decline and brain damage in a rodent model [16]. However, to date the mechanisms underlying IHC-mediated brain tolerance against AD phenotype remain elusive. Taking into account that mitochondria have been posited at the hub of conditioning phenomenon [17-19], the present study was undertaken to investigate if IHC is able to confer a long-lasting protection against $\mathrm{AD}$-related phenotype in the $3 \times \mathrm{Tg}$ - $\mathrm{AD}$ mouse model and to unveil the potential mitoprotective adaptations. $3 \times \mathrm{Tg}$ - $\mathrm{AD}$ has been described as a progressive model of familial AD that develops subtle memory deficits at four months of age, $A \beta$ pathology around 6 months of age and tau pathology after 12 months of age [20]. Herein, six-month-old $3 \times \mathrm{Tg}$-AD mice were submitted to an IHC protocol for a two-week period and mice were sacrificed at nine months of age. In the brain cortex, the following parameters were evaluated: (i) neuropathological hallmarks ( $\mathrm{A} \beta$ and $\mathrm{p}$-tau); (ii) brain glucose metabolism; (iii) mitochondrial bioenergetic function and dynamics (fusion-fission, biogenesis, degradation and transport); and (iv) synaptic integrity and neurotransmitters were evaluated. Behavioral and cognitive performance was evaluated two weeks before the sacrifice of mice.

\section{Results}

\subsection{IHC Partially Prevents Behavioral and Cognitive Alterations in $3 \times \mathrm{Tg}-A D$ Mice}

Ten weeks after the implementation of IHC protocol, the effect of this non-pharmacological strategy on AD-related behavioral and cognitive manifestations was assessed by performing the open-field and Morris water maze (MWM) tests. In the open-field test, the $3 \times \mathrm{Tg}$-AD mice exhibited an increased anxiety-like behavior when compared with the control wild-type (WT) mice, as reflected by the decrease in the total distance travelled (Figure 1A) and time spent 
in the center of the open-field arena (Figure 1B). Notably, IHC was able to avert this anxiety pattern in $3 \times$ Tg-AD mice (Figure $1 \mathrm{~A}, \mathrm{~B}$ ).

A.

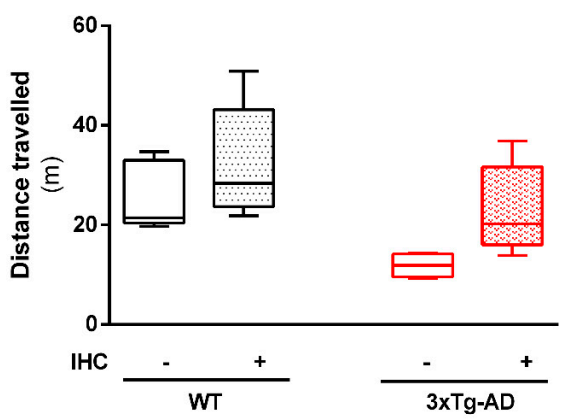

B.

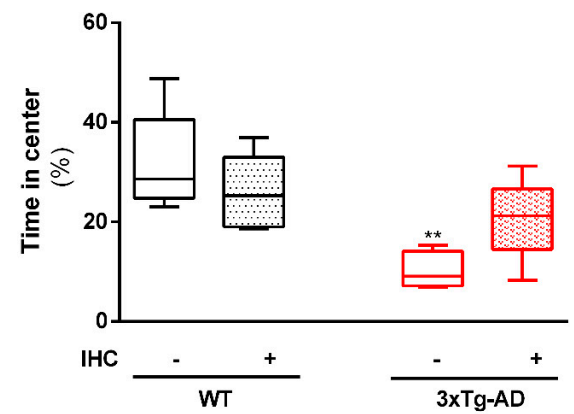

Figure 1. Effect of IHC on locomotor activity and anxiety-like behavior in the $3 \times \mathrm{Tg}$-AD mouse model during the open-field test. (A) Total distance travelled and (B) time spent in the center of the open-field arena during the open field test. Data are presented as box-and-whisker plots representing median and interquartile range (IQR), with minimum and maximum values of 5-9 animals from each experimental condition. Statistical significance: ${ }^{* *} p<0.01$ when compared with control WT mice.

As expected, during the acquisition phase of the MWM test, $3 \times \mathrm{Tg}$-AD mice presented higher escape latencies to find the hidden platform across the four-day training period when compared with the respective control WT mice (Figure 2A). Furthermore, $3 \times \mathrm{Tg}$-AD mice also spent less time in the target quadrant during the retention phase and exhibited a decrease in the number of platform crossings (Figure 2B,C), corroborating the existence of learning and memory deficits in this mouse model of AD. Remarkably, IHC was able to decrease the escape latency time on day 4 of the acquisition phase and increase the time spent in the target quadrant in the retention trial, reflecting a protective effect of IHC against $3 \times \mathrm{Tg}$-AD-related cognitive deterioration (Figure $2 \mathrm{~A}, \mathrm{~B}$ ).

A.

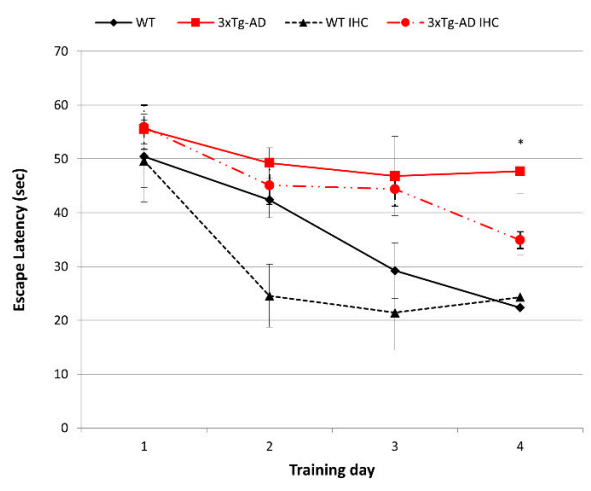

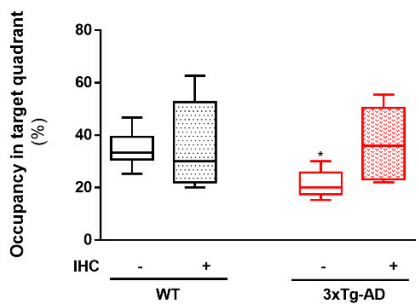

c.

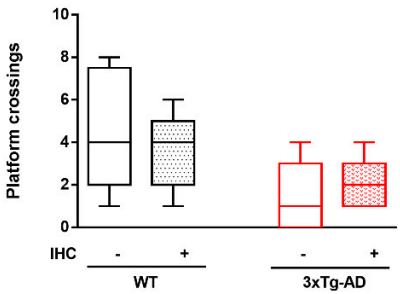

Figure 2. Effect of IHC on learning and spatial memory in the $3 \times$ Tg-AD mouse model during the MWM test. (A) Mean escape latencies to reach the hidden platform during the training trials, which were conducted for 4 consecutive days. (B) The percent time in the target quadrant during the probe trial performed $24 \mathrm{~h}$ after the last training trial. (C) The number of platform crossings during the probe trial. Data are presented as box-and-whisker plots representing median and IQR, with minimum and maximum values of 5-9 animals from each experimental condition. Statistical significance: ${ }^{*} p<0.05$ when compared with control WT mice. 


\subsection{HP Abrogates $A \beta$ Pathology in the Brain Cortex of $3 \times T g-A D$ Mice}

In a step further, the impact of IHC on the neurotoxic proteins of $A D-A \beta$ and phosphorylated tau was evaluated on brain cortical homogenates by immuno-dot-blot and immunoblotting, respectively. Using the $6 \mathrm{E} 10$ antibody, which recognizes $\mathrm{A} \beta$ monomers, fibrils and oligomers, a significant increase in $A \beta$ levels was detected in the brain cortex of $3 \times \mathrm{Tg}$-AD mice when compared with control WT mice. Of note, IHC was able to reduce brain cortical $A \beta$ levels near to those observed in control WT mice (Figure $3 \mathrm{~A}$ ). No significant alterations were observed in the brain cortical levels of AT8, which detects phosphorylated tau protein at Ser202/Thr205 residues, among the experimental groups (Figure 3B).

A.

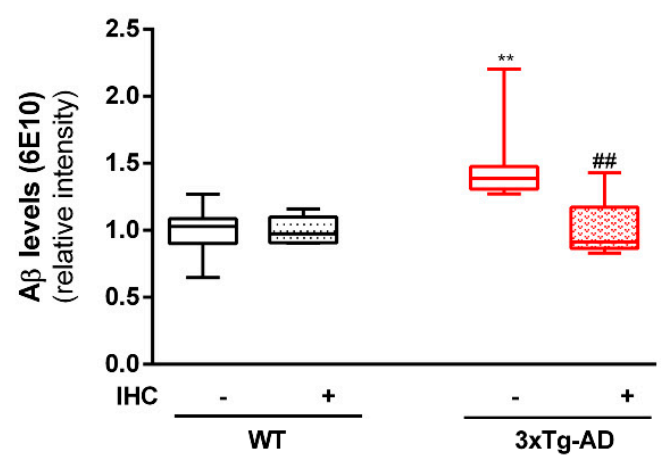

$A \beta(6 E 10)$

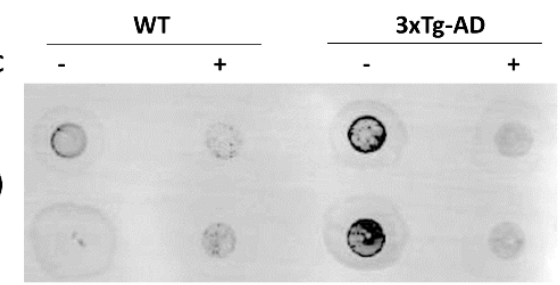

B.
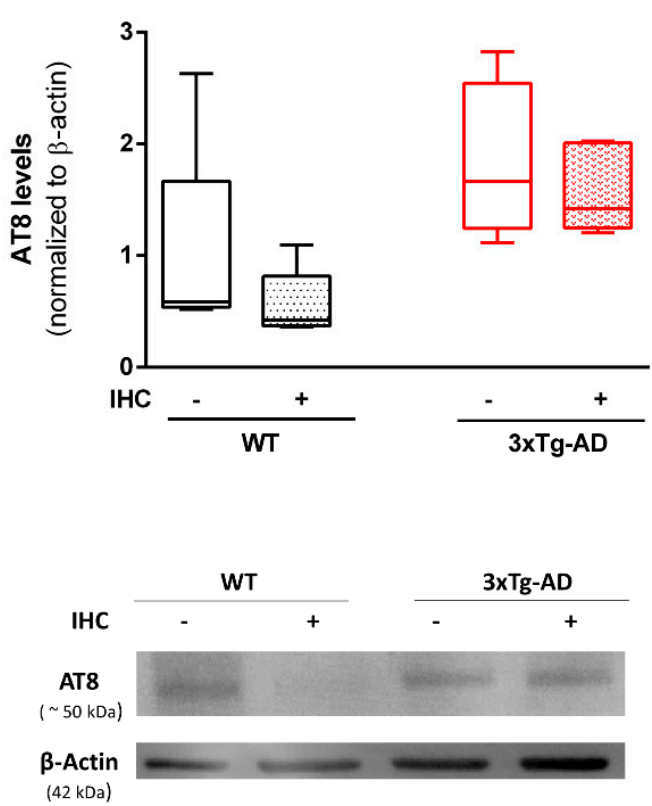

Figure 3. Effect of IHC on AD hallmarks in the brain cortex of $3 \times \mathrm{Tg}-\mathrm{AD}$ mouse model. (A) Using the antibody $6 \mathrm{E} 10$, the A $\beta$ levels were detected by immuno-dot blot. (B) Representative Western blot image and densiometric analysis of tau levels detect with AT8 antibody which recognizes Ser202/Thr205 residues. $\beta$-actin was used as an internal loading control. Data are presented as box-and-whisker plots representing median and IQR, with minimum and maximum values of 5 animals from each experimental condition. Statistical significance: ${ }^{* *} p<0.01$ when compared with control WT mice; ${ }^{\# \#} p<0.01$ when compared with $3 \times \mathrm{Tg}-\mathrm{AD}$ mice.

\subsection{IHC Ameliorates Mitochondrial Bioenergetic Function in the Brain Cortex of $3 \times T g-A D$ Mice}

Dysfunction of brain glucose metabolism and mitochondrial bioenergetics are early events during the pathological course of AD. Importantly, it has been postulated that energetic crisis is an important driving force underlying neuronal loss and cognitive decline in AD [21-23]. Within this scenario, we advocate that IHC might prevent ADrelated brain hypometabolism in the $3 \times \mathrm{Tg}$-AD mouse model. Therefore, in a first approach the levels of some metabolites involved in glycolysis and Krebs cycle were detected in the brain cortex by ${ }^{1} \mathrm{H}$ nuclear magnetic resonance (NMR) spectroscopy and the activity of citrate synthase by spectrophotometry. Interestingly, IHC significantly averted the slight decrease in glucose levels (Figure 4A) and the increase in succinate levels (Figure 4D) in the brain cortex of $3 \times \mathrm{Tg}$-AD mice. Furthermore, $3 \times \mathrm{Tg}-\mathrm{AD}$ rats also abrogated the significant decrease in the citrate synthase activity in the $3 \times \mathrm{Tg}$ - $\mathrm{AD}$ mice, which is known to be the enzyme that catalyzes the first reaction of Krebs cycle (Figure 4E). 
A.

B.

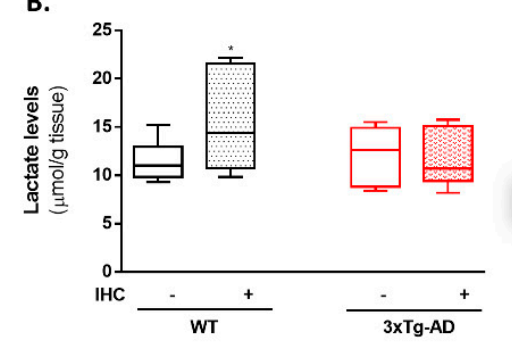

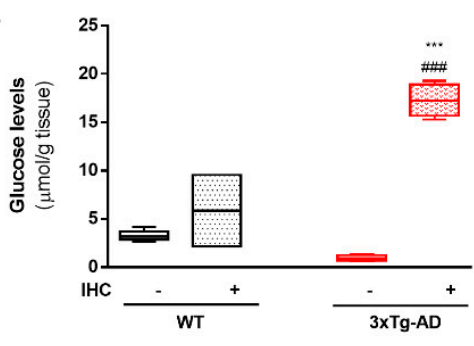

c.

E.
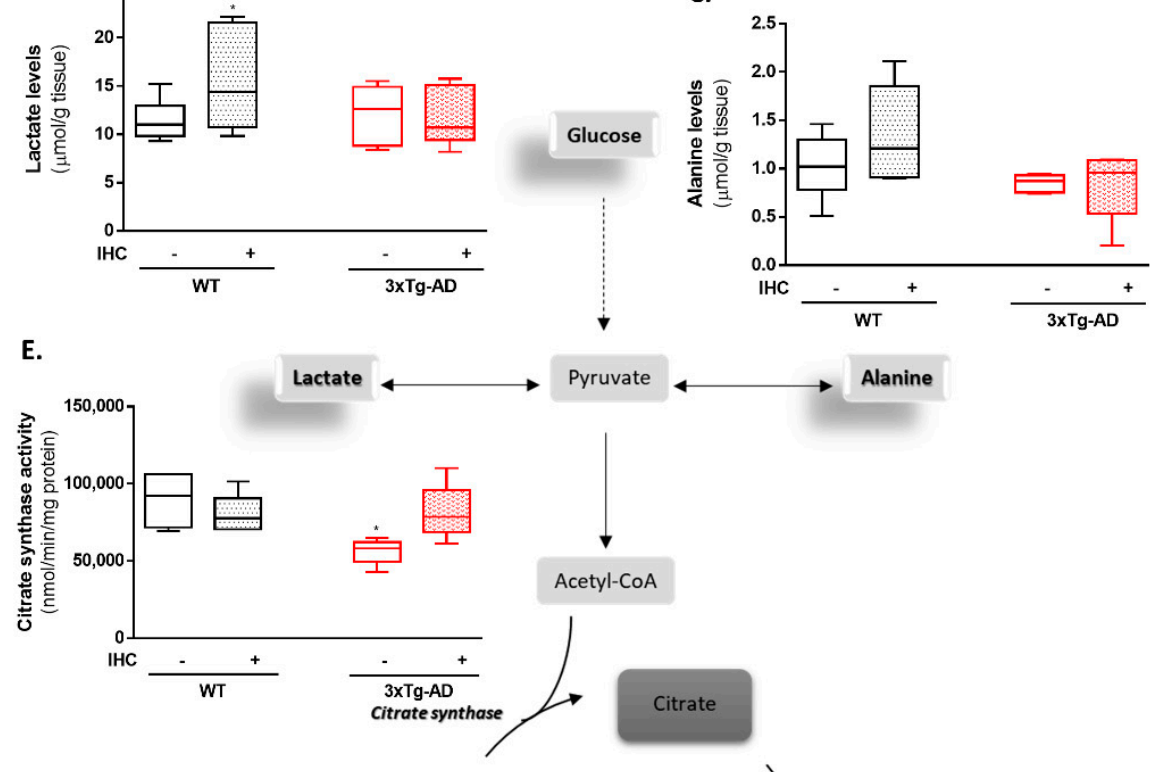

Oxaloacetate

。.

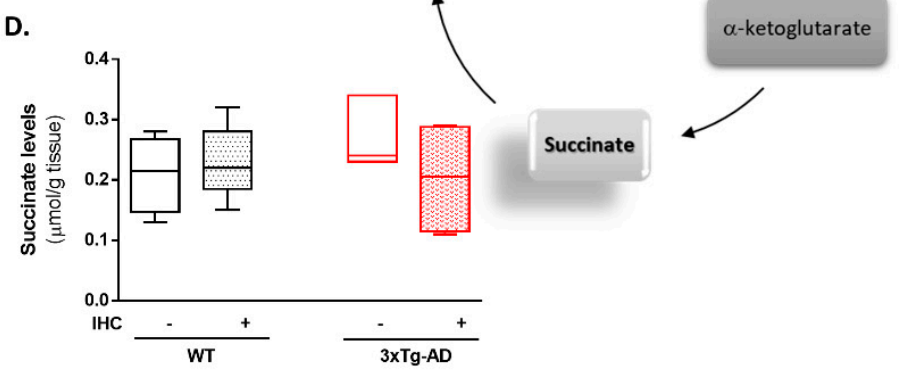

Figure 4. Effect of IHC on energy metabolism in the brain cortex of $3 \times \mathrm{Tg}-\mathrm{AD}$ mouse model. The levels of the metabolites (A) glucose, (B) lactate, (C) alanine, and (D) succinate were detected in the brain cortex by NMR spectroscopy. (E) Citrate synthase activity was measured spectrophotometrically at $412 \mathrm{~nm}$. Data are presented as box-and-whisker plots representing median and IQR, with minimum and maximum values of 5-7 animals from each experimental condition. Statistical significance: ${ }^{*} p<0.05,{ }^{* * *} p<0.001$ when compared with control WT mice; ${ }^{\# \#} p<0.001$ when compared with $3 \times \mathrm{Tg}-\mathrm{AD}$ mice.

In a step further, using freshly isolated brain cortical mitochondria energized with succinate (substrate for the mitochondrial respiratory Complex II), oxidative phosphorylation capacity and mitochondrial respiration were evaluated by polarographic methods. Regarding oxidative phosphorylation system, IHC was shown to promote a significant increase in $\Delta \Psi \mathrm{m}$ and repolarization levels in brain cortical mitochondria from $3 \times \mathrm{Tg}$-AD mice (Table 1). As shown in Table 1, IHC further induced a significant increase in mitochondrial respiratory state 2, RCR and FCCP-stimulated respiration. RCR is a measure of the coupling 
between substrate oxidation and phosphorylation and is a good indicator of mitochondrial integrity. Overall, these data suggest that IHC strongly improves mitochondrial coupling and respiratory efficiency in the brain cortex of $3 \times \mathrm{Tg}$ - $\mathrm{AD}$ mice.

Table 1. Effect of IHC on brain cortical oxidative phosphorylation system and mitochondrial respiratory function in the $3 \times \mathrm{Tg}-\mathrm{AD}$ mouse model.

\begin{tabular}{|c|c|c|c|c|c|}
\hline & & WT & WT IHC & $3 \times \mathrm{Tg}-\mathrm{AD}$ & $3 \times$ Tg-AD IHC \\
\hline \multirow{3}{*}{$\begin{array}{c}\text { Oxidative } \\
\text { Phosphorylation } \\
\text { System }\end{array}$} & $\Delta \Psi(-\mathrm{mV})$ & $220.1 \pm 3.16$ & $222.3 \pm 5.14$ & $204.6 \pm 3.73$ & $221.4 \pm 4.65^{\#}$ \\
\hline & $\begin{array}{c}\text { Repolarization } \\
\text { level }(-\mathrm{mV})\end{array}$ & $217.0 \pm 2.26$ & $223.7 \pm 4.66$ & $205.7 \pm 2.7$ & $223.6 \pm 4.57^{\# \#}$ \\
\hline & $\begin{array}{c}\text { Repolarization lag } \\
\text { phase (min) }\end{array}$ & $0.73 \pm 0.047$ & $0.69 \pm 0.042$ & $0.85 \pm 0.086$ & $0.67 \pm 0.045$ \\
\hline \multirow{5}{*}{$\begin{array}{l}\text { Mitochondrial } \\
\text { respiratory } \\
\text { function }\end{array}$} & $\begin{array}{c}\text { State } 2 \\
\text { (nAtgO/min } / \mathrm{mg})\end{array}$ & $39.09 \pm 2.31$ & $35.22 \pm 2.12$ & $28.46 \pm 2.56$ & $43.44 \pm 5.47^{\#}$ \\
\hline & $\mathrm{RCR}$ & $3.80 \pm 0.14$ & $3.69 \pm 0.36$ & $3.26 \pm 0.09 *$ & $3.55 \pm 0.17$ \\
\hline & $\begin{array}{c}\text { ADP/O } \\
(\mathrm{nmol} \text { ADP/ } \\
\text { AtgO/min/mg) }\end{array}$ & $3.94 \pm 0.35$ & $4.06 \pm 0.36$ & $4.04 \pm 0.48$ & $4.03 \pm 0.34$ \\
\hline & $\begin{array}{c}\text { Oligomycin- } \\
\text { inhibited } \\
\text { respiration } \\
\text { (nAtgO/min/mg) }\end{array}$ & $32.49 \pm 2.32$ & $40.77 \pm 8.37$ & $25.32 \pm 1.91$ & $36.20 \pm 4.67$ \\
\hline & $\begin{array}{l}\text { FCCP-stimulated } \\
\text { respiration } \\
(\mathrm{nAtgO} / \mathrm{min} / \mathrm{mg}))\end{array}$ & $101.2 \pm 11.02$ & $114.0 \pm 23.75$ & $69.78 \pm 5.82 *$ & $119.9 \pm 16.75$ \\
\hline
\end{tabular}

Mitochondrial parameters were evaluated in freshly isolated brain cortical mitochondrial fractions $(0.8 \mathrm{mg})$ in $1 \mathrm{~mL}$ of the reaction medium energized with $5 \mathrm{mM}$ succinate (substrate for complex II) in the presence of $2 \mu \mathrm{M}$ rotenone. Data are the mean \pm SEM of 5-7 animals from each experimental condition studied. Statistical significance: * $p<0.05$ when compared with control WT mice; ${ }^{\#} p<0.05,{ }^{\# \#} p<0.01$ when compared with $3 \times \mathrm{Tg}-\mathrm{AD}$ mice. Abbreviations: $\Delta \Psi \mathrm{m}$-mitochondrial membrane potential; RCR—respiratory control ratio.

\subsection{IHC Reduces the Levels of Mitochondrial Fission-Related Proteins in the Brain Cortex of $3 \times T g-A D$ Mice}

In face of this robust improvement of the brain bioenergetic profile, we asked whether the mitochondrial quality control mechanisms could be acting on the protective effect afforded by IHC paradigm against AD phenotype. The mitochondrial network can be reconfigured due to alterations in the metabolic state. It is well-known that mitochondrial network morphology is governed by two opposing processes, mitochondrial fusion and mitochondrial fission. Frequent cycles of fusion and fission contribute to the maintenance of mitochondrial function and optimize bioenergetic capacity [24,25]. Therefore, the next step of this study was to determine by immunoblotting the brain cortical levels of the mitochondrial shaping proteins, optic atrophy protein-1 (OPA-1), mitofusin-1 (Mnf-1) and mitofusin-2 (Mnf-2), which control the mitochondrial fusion process, and fission protein 1 (Fis1) and dynamin-like protein 1 (DRP1), which regulate mitochondrial fission. At nine months of age and compared with the control WT mice, $3 \times \mathrm{Tg}-\mathrm{AD}$ mice only presented a slight increase in the active form of the fission protein DRP1 ( $\mathrm{p}^{\text {Ser616-DRP1) }}$ (Figure 5D). Remarkably, IHC induced a significant increase in the levels of mitochondrial fusion protein Mnf-2 (Figure 5C) and a significant decrease in the active form of DRP1 (Figure 5D) and Fis1 (Figure 5E) in the brain of $3 \times \mathrm{Tg}-\mathrm{AD}$ mice, suggesting a shift of mitochondrial network dynamics towards mitochondrial fusion. 
A.

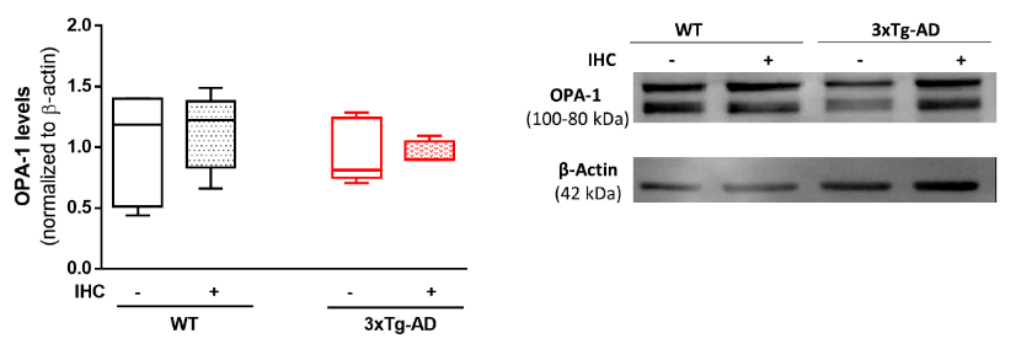

B.
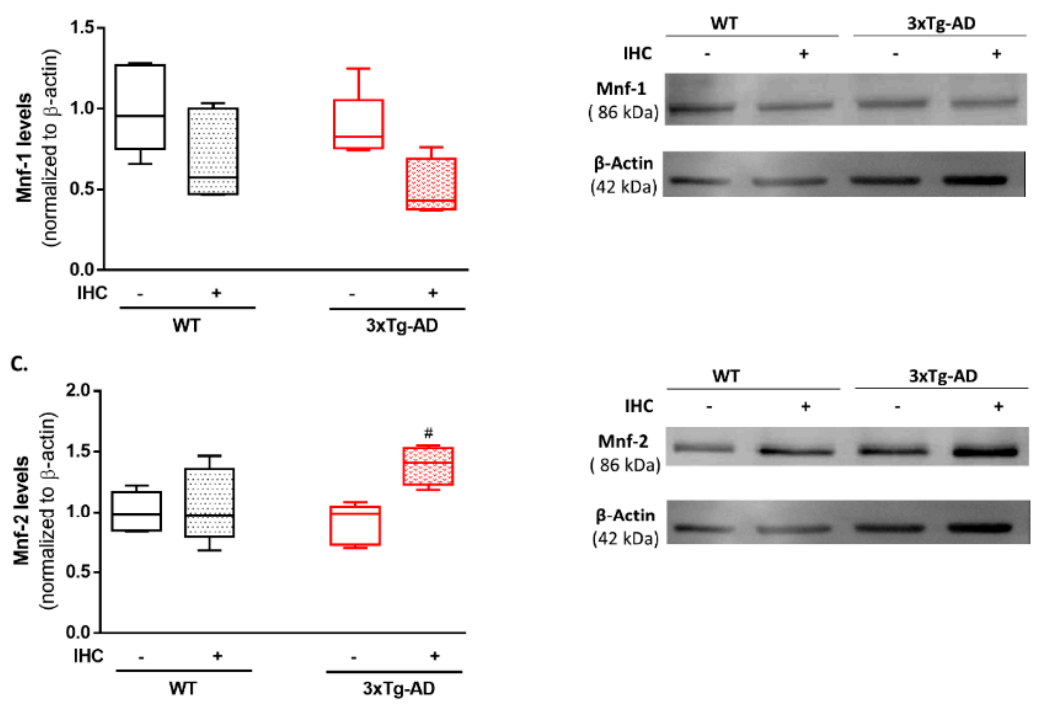

D.
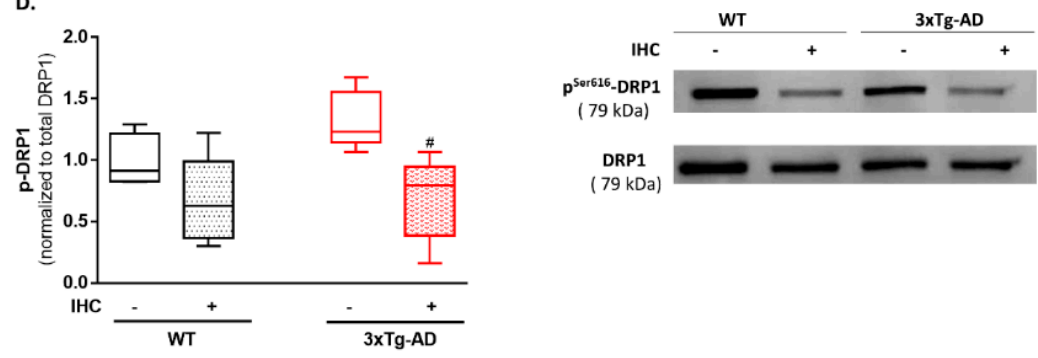

E.
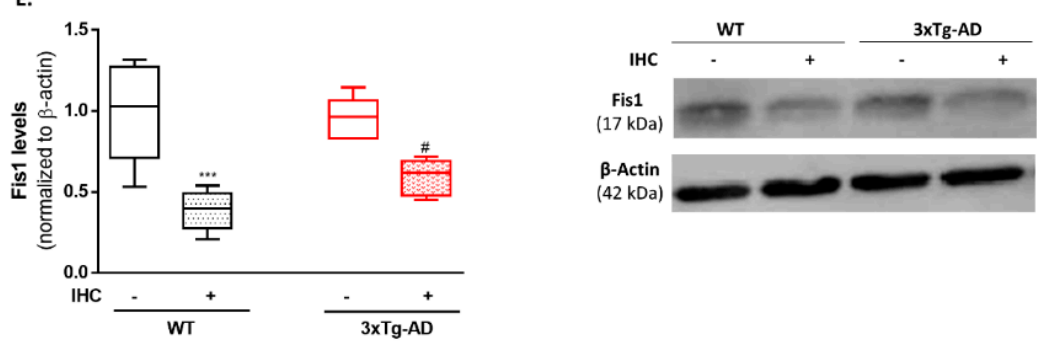

Figure 5. Effect of IHC on mitochondrial fusion-fission machinery in the brain cortex of $3 \times \mathrm{Tg}-\mathrm{AD}$ mouse model. (A) Representative Western blot image and densiometric analysis of OPA-1, (B) Mnf-1, (C) Mnf-2, (D) DRP1 (E) Fis1 protein levels. $\beta$-actin was used as an internal loading control. Active form of DRP1 ( $\mathrm{p}^{\text {Ser616 }}$-DRP1) was normalized to total DRP1 levels. Data are presented as box-andwhisker plots representing median and IQR, with minimum and maximum values of 5 animals from each experimental condition. Statistical significance: ${ }^{* * *} p<0.001$ when compared with control WT mice; ${ }^{\#} p<0.05$ when compared with $3 \times \mathrm{Tg}$-AD mice. 


\subsection{IHC Promotes Mitochondrial Biogenesis Increasing Mitochondrial Content in the Brain Cortex of $3 \times \mathrm{Tg}-A D$ Mice}

In response to the bioenergetic demand, new mitochondria are de novo synthesized in a process termed mitochondrial biogenesis. To gain further insights on the mitoprotective events underlying the rescuing of mitochondrial bioenergetic profile mediated by IHC, mitochondrial biogenesis was evaluated by assessing the protein levels of TFAM, one of the main effectors that regulate mitochondrial DNA (mtDNA) transcription, and TOM20, a mitochondrial outer membrane protein that functions as a reliable marker of mitochondrial mass. Our results revealed a modest decrease on TFAM and TOM20 protein levels in the brain cortex of $3 \times \mathrm{Tg}$ - $\mathrm{AD}$ mice, when compared with the respective control WT mice (Figure 6A,B). However, IHC was able to significantly increase TFAM and TOM20 protein levels in the brain cortex of $3 \times \mathrm{Tg}-\mathrm{AD}$ mice (Figure $6 \mathrm{~A}, \mathrm{~B}$ ). To corroborate these findings, mitochondrial mass was also evaluated by determining the mtDNA content by real-time qPCR (RT-PCR). Consistently, IHC was able to induce a significant increment in the relative mtDNA copy number in the brain cortex of $3 \times \mathrm{Tg}$-AD mice (Figure $6 \mathrm{C}$ ).

A.

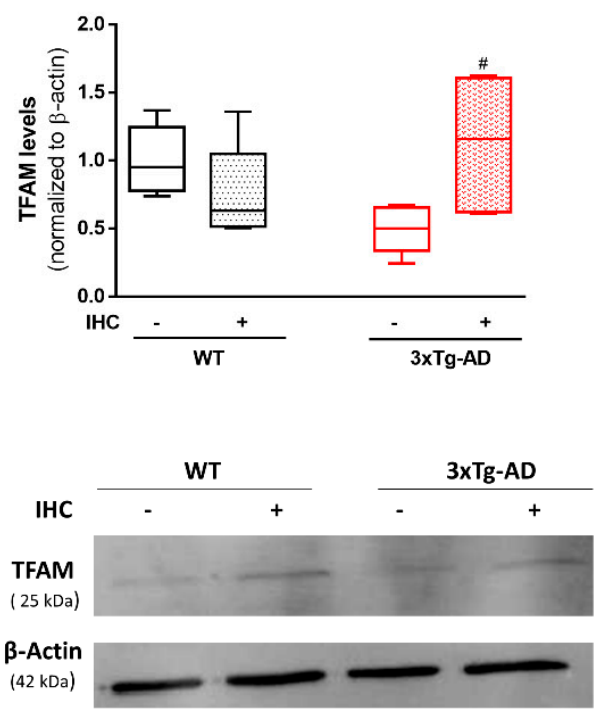

B.
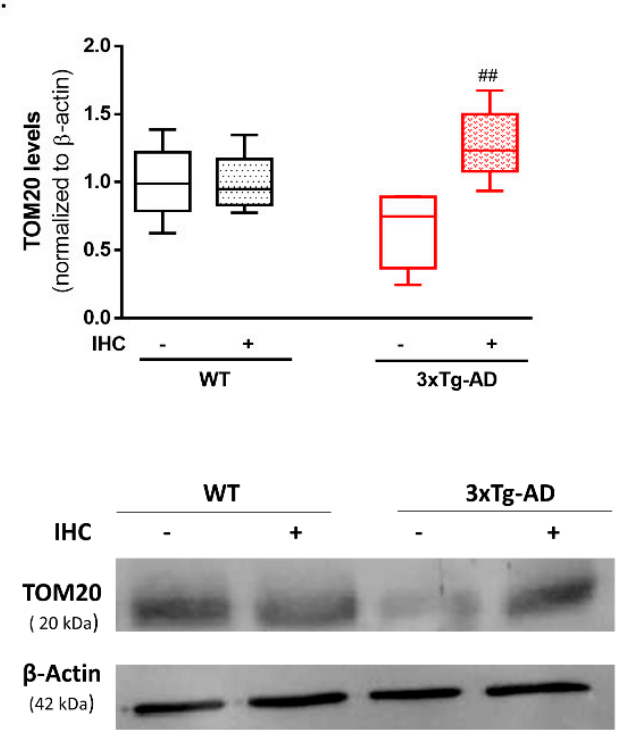

C.

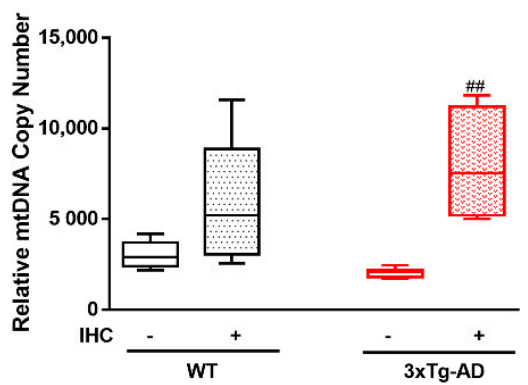

Figure 6. Effect of IHC on mitochondrial biogenesis in the brain cortex of $3 \times$ Tg-AD mouse model. (A) Representative Western blot image and densiometric analysis of TFAM and (B) TOM20 protein levels. $\beta$-actin was used as an internal loading control. (C) The relative mtDNA copy number was determined by RT-PCR. Data are presented as box-and-whisker plots representing median and IQR, with minimum and maximum values of 5 animals from each experimental condition. Statistical significance: ${ }^{\#} p<0.05,{ }^{\# \#} p<0.01$ when compared with $3 \times \mathrm{Tg}$-AD mice.

\subsection{IHC Enhances the Molecular Machinery Behind Mitophagy in the Brain Cortex of $3 \times \mathrm{Tg}$ - AD Mice}

Besides mitochondrial fusion-fission and mitochondrial biogenesis, the selective degradation of damaged or unwanted mitochondria by mitophagy constitutes another crucial checkpoint of the mitochondrial quality control axis. Briefly, the reduction of $\Delta \Psi \mathrm{m}$ function as an "eat me" signal that is sensed by PTEN-induced kinase (PINK1), which in turn recruits Parkin to the damaged mitochondria. Subsequently, active Parkin leads to the ubiquitination of mitochondrial proteins which serves as a distinct molecular code required for the selective recruitment of autophagy machinery and the completion of mitophagy [26,27]. We hypothesized that increased mitophagy could represent an adaptative event underlying the improvement of mitochondrial bioenergetic profile in the $3 \times$ Tg-AD mice submitted to the IHC protocol. To this end, the protein levels of PINK-1, Parkin, Lysosomal-associated membrane protein 1 (LAMP-1, a standard marker for lyso- 
somes) and microtubule-associated protein light chain 3-II (LC3-II, a standard marker for autophagosomes) were detected by immunoblotting. In comparison with the control WT mice, $3 \times \mathrm{Tg}-\mathrm{AD}$ mice presented a significant increase in Parkin and LAMP-1 protein levels (Figure 7B,C), suggesting a failure during the mitophagic process. However, our results revealed that IHC promoted a significant increase in Parkin and LC3-II protein levels (Figure 7B,D) and a significant decrease in PINK-1 and LAMP-1 protein levels (Figure 7A,C), fostering the idea that IHC promotes the efficient removal of dysfunctional mitochondria in order to sustain mitochondrial bioenergetics.

A.

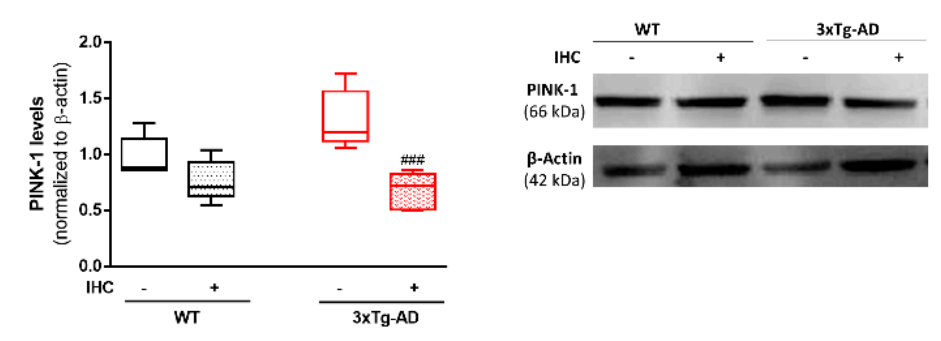

B.
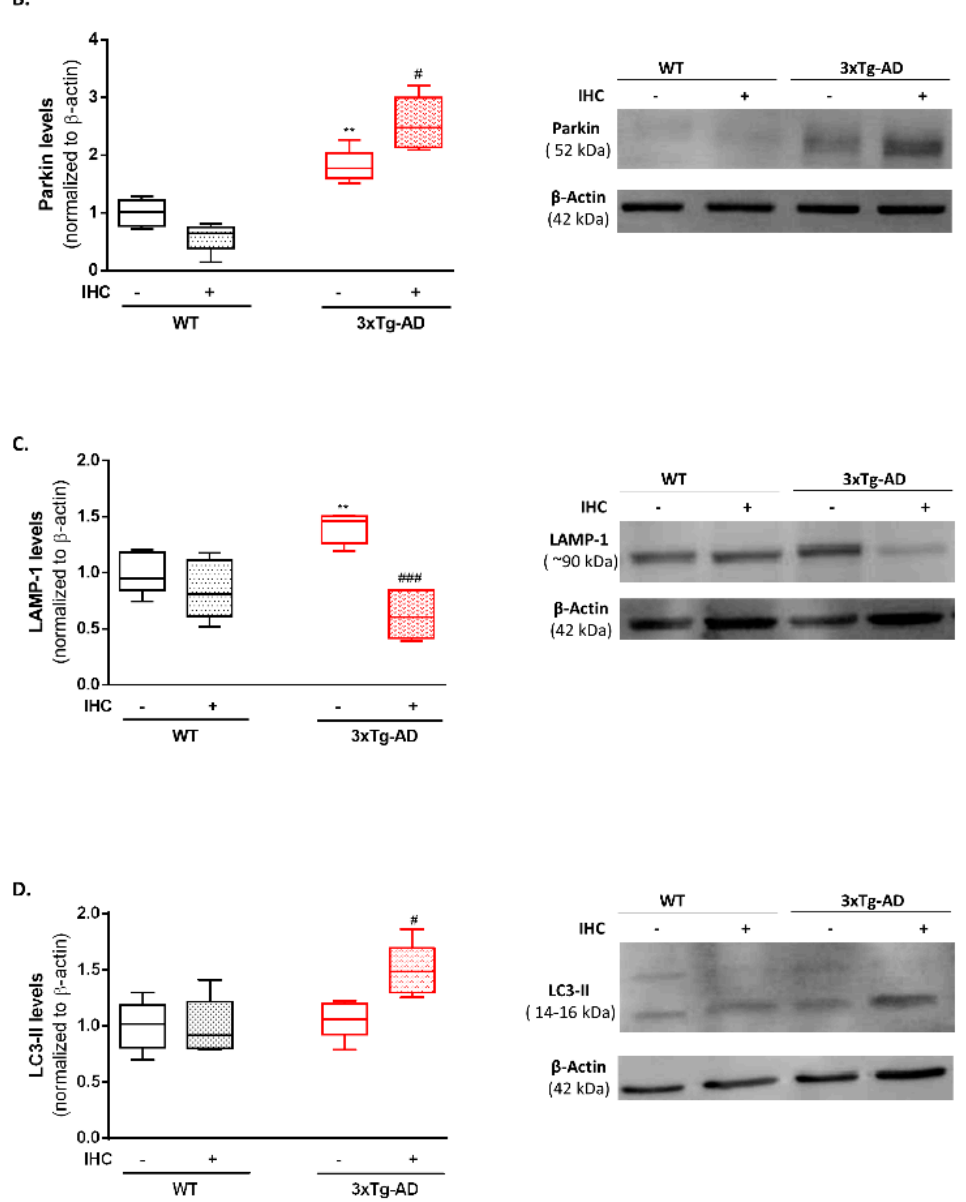

Figure 7. Effect of IHC on mitophagy-related markers in the brain cortex of $3 \times \mathrm{Tg}$-AD mouse model. (A) Representative Western blot image and densiometric analysis of PINK-1, (B) Parkin, (C) LAMP-1 and (D) LC3-II protein levels. $\beta$-actin was used as an internal loading control. Data are presented as box-and-whisker plots representing median and IQR, with minimum and maximum values of 5 animals from each experimental condition. Statistical significance: ${ }^{*} p<0.01$ when compared with control WT mice; ${ }^{\#} p<0.05,{ }^{\# \#} p<0.001$ when compared with $3 \times \mathrm{Tg}$-AD mice. 


\subsection{IHC Increases Mitochondrial Motor Proteins in the Brain Cortex of $3 \times T g-A D$ Mice}

The vigorous transport of mitochondria in both anterograde and retrograde directions is crucial to distribute functional mitochondria according to the energetics requirements of the different neuronal compartments and to remove dysfunctional mitochondria, respectively $[28,29]$. In this sense, to gain further insights into the long-lasting mitoprotective effects of IHC phenomenon, the levels of the motor proteins dynein and kinesin family member 5B (KIF-5B) and the mitochondrial-anchoring protein syntaphilin were detected in the brain cortex. The $3 \times \mathrm{Tg}$-AD mice exhibited a slight decrease in KIF-5B protein levels (Figure 8B) and a significant increase in syntaphilin protein levels (Figure 8C), when compared with the respective control WT mice. Notably, IHC was able to significantly increase both dynein and KIF-5B and decrease syntaphilin protein levels in the brain cortex of $3 \times \mathrm{Tg}$-AD mice (Figure $8 \mathrm{~A}-\mathrm{C}$ ) suggesting that IHC enhances the bidirectional transport of mitochondria, favoring the distribution of new mitochondria to the synaptic terminal and mitophagy.

A.

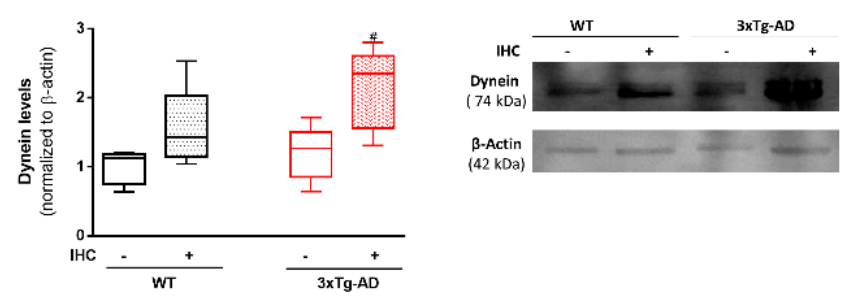

B.

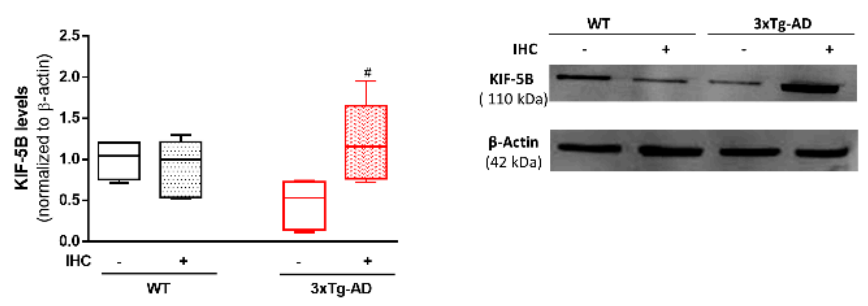

c

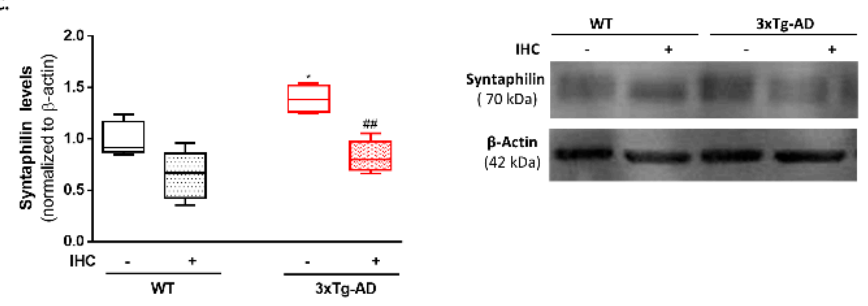

Figure 8. Effect of IHC on mitochondrial transport-related proteins in the brain cortex of $3 \times \mathrm{Tg}-\mathrm{AD}$ mouse model. (A) Representative Western blot image and densiometric analysis of dynein, (B) KIF-5B and (C) syntaphilin protein levels. $\beta$-actin was used as an internal loading control. Data are presented as box-and-whisker plots representing median and IQR, with minimum and maximum values of 5 animals from each experimental condition. Statistical significance: ${ }^{*} p<0.05$ when compared with control WT mice; ${ }^{\#} p<0.05$, ${ }^{\# \#} p<0.01$ when compared with $3 \times \mathrm{Tg}$-AD mice. 


\subsection{IHC Downregulates SNAP-25 and Increases Glutamate and GABA Levels and in the Brain} Cortex of $3 \times \mathrm{T} g-A D$ Mice

Given the importance of mitochondrial network dynamics for the maintenance of synaptic integrity and functioning, in this last set of experiments the levels of the presynaptic proteins, SNAP-25 and synaptotagmin-I, and the post-synaptic density protein-95 (PSD-95) were evaluated by immunoblotting. As shown in Figure 9B, only a modest decrease in synaptotagmin-I was detected in the brain cortex of the $3 \times \mathrm{Tg}$-AD mice, when compared with the respective control WT mice. Surprisingly, IHC promoted a significant decrease in SNAP- 25 protein levels in the brain cortex of WT and $3 \times \mathrm{Tg}$-AD mice (Figure 9A). This result raises the possibility that the reduction in SNAP-25 may constitute an adaptive response triggered by IHC to sustain synaptic and neuronal integrity and, thus preserve cognitive functions.

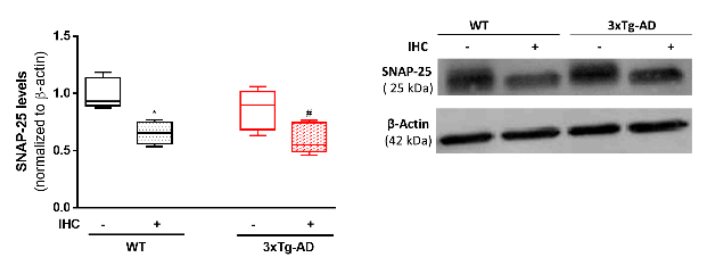

B.
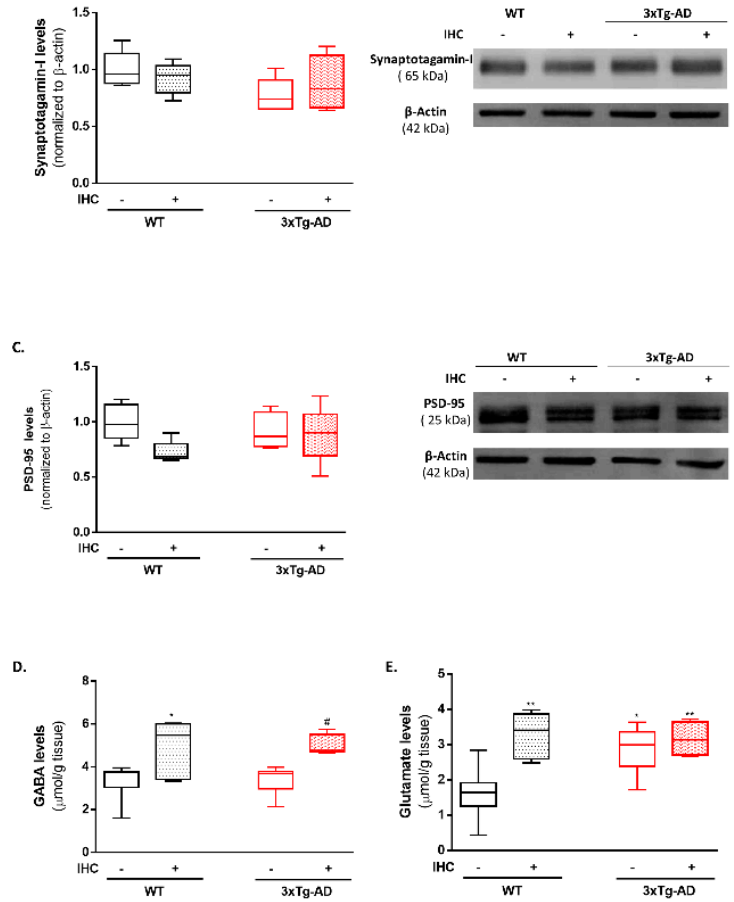

Figure 9. Effect of IHC on synaptic integrity markers and neurotransmitters levels in the brain cortex of $3 \times \mathrm{Tg}$-AD mouse model. (A) Representative Western blot image and densiometric analysis of SNAP-25, (B) synaptotagamin-I and (C) PSD-95 protein levels. $\beta$-actin was used as an internal loading control. The levels of the neurotransmitters (D) GABA and (E) glutamate were detected in the hippocampus by NMR spectroscopy. Data are presented as box-and-whisker plots representing median and IQR, with minimum and maximum values of 5 animals from each experimental condition. Statistical significance: ${ }^{*} p<0.05,{ }^{* *} p<0.01$ when compared with control WT mice; ${ }^{*} p<0.05$, \# $p<0.01$ when compared with $3 \times \mathrm{Tg}$-AD mice.

Lastly, the brain cortical levels of the neurotransmitters GABA and glutamate were also measured by NMR spectroscopy. When compared with the control WT mice, $3 \times \mathrm{Tg}$ AD mice exhibited a significant increase in glutamate levels (Figure 9E). Interestingly, 
IHC induced a significant increase in the levels of GABA and glutamate on both WT and $3 \times \mathrm{Tg}-\mathrm{AD}$ mice (Figure 9D,E).

\section{Discussion}

Dovetailing in the old saying "what doesn't kill you makes you stronger", conditioning is known to trigger an adaptive reprogramming of the brain, enhancing the resilience to disease conditions. Within this scenario, the present study was designed to extend the knowledge regarding the potential protective impact of IHC against AD-related phenotype, putting a special focus on the different aspects of mitochondrial (patho)biology. Taking advantage from the $3 \times \mathrm{Tg}-\mathrm{AD}$ mouse model of $\mathrm{AD}$, this study revealed that the implementation of IHC protocol during a two-week period (Figure 10) was able to confer long-term protective effects on behavior and cognitive performance, $A \beta$ pathology and mitochondrial bioenergetic function. Interestingly, the boost on mitochondrial bioenergetic profile was accompanied by: (i) a reduction in mitochondrial fission proteins DRP1 and Fis1 and an increase in mitochondrial fusion protein Mnf-2; (ii) stimulation of mitochondrial biogenesis and mitophagy; and (iii) modulation of the bidirectional transport of mitochondria as denoted by the increase in motor proteins dynein and KIF-5B.

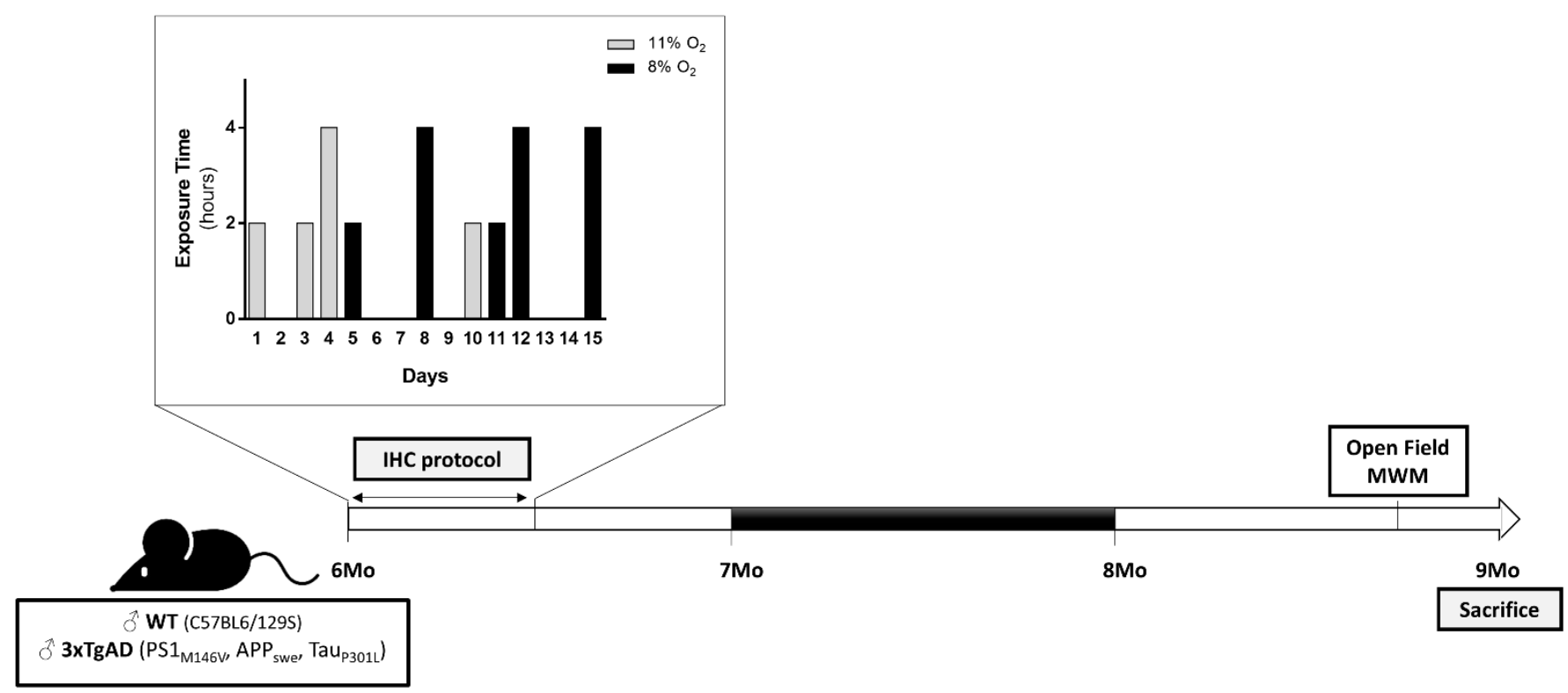

Figure 10. Experimental design. 6-month-old male WT and $3 \times \mathrm{Tg}-\mathrm{AD}$ mice were randomly divided into two groups: (i) a conditioned and (ii) a non-conditioned control group. In the IHC paradigm, mice were exposed to 9 hypoxic episodes over 2 weeks for either 2 or $4 \mathrm{~h}$ at either $8 \%$ or $11 \% \mathrm{O}_{2}$ during a 2-week period. Open-field and MWM tests were performed around 8.5-month-old. Mice were euthanized at 9 months of age.

One of the major challenges for the scientific community is to develop a "magic pill" able to halt and/or reverse AD-related behavioral disturbances and cognitive decline. As aforementioned, the conundrum for $\mathrm{AD}$ therapy concerns with the fact that the degenerative events behind the selective neuronal loss precede the clinical signs of the disease by decades [6]. In this study, a IHC protocol was employed to 6-month-old $3 \times \mathrm{Tg}-\mathrm{AD}$ mice, which already exhibit AD-like symptomatology at this age [30]. Remarkably, this non-pharmacological procedure was able to avert the anxiety behavior and the memory and learning deficits in $3 \times \mathrm{Tg}$ - $\mathrm{AD}$ mice (Figures 1 and 2), as mirrored by longer time spent in the center of the open-field arena and lower escape latencies to reach the hidden platform and by the increased time spent in the target quadrant in the retention trial of the MWM test. Similarly, using a non-transgenic rat model of AD, Manukhina and collaborators [16] found that IHC (14 days, $4 \mathrm{~h}$ per day, simulating an altitude of $4000 \mathrm{~m}$ ) protected cognitive functions by blocking memory degradation assessed 14 days after $\mathrm{A} \beta$ 
administration. In the same line, IHC was also shown to improve cognitive performance and reduce anxiety-related behavior in APP/PS1 mice [31]. Besides these promising results in rodent models of $\mathrm{AD}$, recent breakthroughs also revealed that intermittent hypoxia training improves short-term memory and attention in elderly patients with amnestic mild cognitive impairment (aMCI), often considered a prodromal phase of AD [32].

Despite the mechanisms underlying AD onset remain puzzling, scientific efforts suggest that $A \beta$ and phosphorylated tau are important triggers, mediators and aggravators of $\mathrm{AD}$ pathology, acting in both separate and synergistic ways to the degenerative events that occur in AD brain [33-35]. Notably, our results revealed that IHC was able to significantly reverse $\mathrm{A} \beta$ levels in the brain cortex of nine-month-old $3 \times \mathrm{Tg}$ - $\mathrm{AD}$ mice (Figure $3 \mathrm{~A}$ ). In the same line, Meng and collaborators [31] observed that IH exposure significantly reduced the number of $A \beta$ plaques in the brain cortex and hippocampus of APP/PS1 mouse model. On the flipside, a study performed in 2013 demonstrated that chronic intermittent hypoxia/reoxygenation $\left(5 \% \mathrm{O}_{2}\right.$ and $21 \% \mathrm{O}_{2}$ every $10 \mathrm{~min}, 8 \mathrm{~h} /$ day for four weeks) favors the generation and accumulation of $A \beta 42$ in the brain of six-month-old $3 \times \mathrm{Tg}$-AD mice [36]. Concerning tau pathology, no alterations in AT8 levels were observed among the experimental groups (Figure $3 \mathrm{~B}$ ). However, compelling evidence points out that intermittent hypoxia differentially modulates endogenous tau phosphorylation [37,38]. Overall, these data draw attention to the fact that intermittent hypoxia can have distinct effects depending on the nature of the hypoxic episodes (i.e., severity, duration, number of episodes per day).

The early stages of AD are marked by a hypometabolic state, as noticed by hampered brain glucose metabolism [39], impaired activities of the Krebs cycle enzymes [40,41], and defects in the mitochondrial electron transport chain [42-45] with the consequent depletion of ATP levels. Lessons from clinical and experimental studies advocate that disturbances in brain energy metabolism are due to a convergence of $A \beta$ and tau on mitochondria, favoring a vicious cycle of deleterious events [46]. Back to 2012, data from our laboratory demonstrated that brain mitochondria from 11-month-old $3 \times \mathrm{Tg}$-AD mice are characterized by and impaired bioenergetic function, decreased $\mathrm{Ca}^{2+}$ buffering capacity and ultrastructural abnormalities [47]. In this study, IHC phenomenon was shown to rescue brain energy metabolism in $3 \times \mathrm{Tg}$ - $\mathrm{AD}$ mice as denoted by the increase in brain cortical levels of glucose and citrate synthase activity (Figure 4). Furthermore, IHC also abolished the defects in oxidative phosphorylation system and mitochondrial respiratory function detected in brain cortical mitochondria isolated from $3 \times \mathrm{Tg}$-AD mice (Table 1). Of note, IHC was able to restore $\triangle \Psi \mathrm{m}$ and RCR and to significantly increase FCCP-stimulated respiration, suggesting that IHC strongly boost mitochondrial bioenergetic capacity. Consistently, IHC was shown to protect brain mitochondrial function, namely cytochrome $c$ oxidase activity in other models of brain disorders [48,49]. However, whether IHC improves mitochondrial bioenergetic function remains unclear. Are mitochondrial quality and quantity control mechanisms targeted by this non-pharmacological strategy?

Aside from the well-characterized metabolic fingerprint, it has been documented a massive accumulation of mitochondria with an altered morphology in dystrophic neurites during the pathological course of $\mathrm{AD}[28,50,51]$. Considering the dynamic nature of mitochondria, it has been proposed that this overcrowding of mitochondria with a defective morphology result from the catastrophic combination of excessive mitochondrial fission, impaired mitochondrial biogenesis, inefficient mitophagy, and faulty mitochondrial transport [52]. Indeed, fluctuations in brain metabolic status are often accompanied by a remodeling of the mitochondrial network [53]. Mitochondrial morphology is controlled by the fine-tunning balance between opposing fusion and fission events. A shift towards mitochondrial fusion favors the generation of an interconnected mitochondrial network, whereas a shift towards mitochondrial fission produces multiple mitochondrial fragments [54]. Using postmortem hippocampal tissue from AD individuals, a pioneer study from Wang and collaborators [55] reported reduced levels of the mitochondrial fusion proteins OPA-1, Mnf- 1 and Mnf-2. In AD cybrids it was observed increased translo- 
cation of the mitochondrial fission DRP1 to mitochondria and reduced Mnf-2 protein levels, culminating in the fragmentation of the mitochondrial network [56]. Consistently, a recent

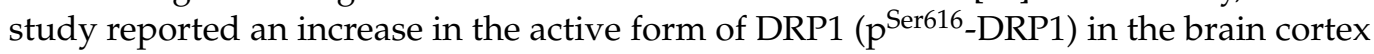
and hippocampus of 10-month-old female $3 \times \mathrm{Tg}$ - $\mathrm{AD}$ mice, bolstering the idea that $\mathrm{AD}$ is marked by excessive mitochondrial fission [57]. Our results revealed only a modest increase in the active form of DRP1 in the brain cortex of $3 \times \mathrm{Tg}$-AD mice (Figure 5D). However, IHC induced a significant increase in Mnf-2 levels and a notorious decrease in both DRP1 and Fis1, suggesting that IHC favors mitochondrial fusion. Under conditions of moderate cellular stress, increased fusion, forming a hyperfused meshwork constitute an adaptive strategy to preserve metabolic homeostasis and cell survival [58]. Notably, mitochondrial fusion is an important mechanism that allows the exchange of lipid membrane and intramitochondrial contents between different mitochondria to enable mtDNA repair and equally distribute metabolites to maintain a healthy mitochondrial population [59]. In this sense, it is alluring to speculate that the shift in mitochondrial fusion-fission machinery towards fusion induced by IHC represents an adaptive mechanism to restore mitochondrial bioenergetic function in $3 \times \mathrm{Tg}-\mathrm{AD}$ mice.

Mitochondrial bioenergetic function is also reliant on mitochondrial mass and turnover. Therefore, another potential explanation for the long-lasting protective effect of IHC on mitochondrial bioenergetics in $3 \times \mathrm{Tg}$ - $\mathrm{AD}$ mice may also rely on the stimulation of mitochondrial biogenesis. Compromised mitochondrial biogenesis, manifested by reduced peroxisome proliferator activator receptor gamma-coactivator $1 \alpha$ (PGC-1 $\alpha)$ and nuclear respiratory factors (NRFs) levels and mtDNA content has been documented in human $\mathrm{AD}$ brain tissue and in in vitro and in vivo models of the disease $[60,61]$. Consistently, our results showed a modest reduction in TFAM and TOM20 levels and mtDNA content in the brain cortex of $3 \times \mathrm{Tg}-\mathrm{AD}$ mice (Figure 6 ). Remarkably, these alterations were abrogated by IHC phenomenon. In line with this finding, transient hypoxia was previously demonstrated to activate a nuclear-encoded regulatory program that stimulates mitochondrial biogenesis [62]. Consequently, this program led to an increase in mtDNA transcription and content, followed by structural evidence of neuronal mitochondrial biogenesis (increased neuronal mitochondria number and/or volume density) [62].

Side by side with mitochondrial biogenesis, the selective removal of damaged or unwanted mitochondria by mitophagy also represents an important "mitocheckpoint" responsible for the maintenance of mitochondrial quantity and quality [63]. Evidence from the literature revealed that $\mathrm{AD}$ progression is associated with the aberrant accumulation of undesirable and irreparable damaged mitochondria due to a failure in the recruitment of the autophagic components to mitochondria [64]. Mitophagy failure in sporadic AD is related with a defective labeling of mitochondria to be degraded by mitophagy, whereas in familial $\mathrm{AD}$, mitochondria are correctly tagged for recycling but a deficiency in the degradation step of the mitophagic process occurs $[65,66]$. In our mice model of familial AD, a significant increase in Parkin (Figure 7B) and LAMP-1 levels (Figure 7C) was detected, suggesting an increase in lysosomal mass due to a failure in the degradation phase of mitophagy. IHC induced a significant increase in Parkin (Figure 7B) and LC3-II levels (Figure 7D) and a reduction in PINK-1 (Figure 7A) and LAMP-1 levels (Figure 7C), indicating that IHC facilitates the efficient removal of dysfunctional mitochondria. Similarly, a previous study demonstrated that conditioning paradigm is able to mitigate ischemia-triggered brain damage by promoting Parkin-dependent mitophagy [67].

Mitochondrial trafficking is another dynamic property of mitochondrial biology, being essential to distribute new and functional mitochondria according to the energetic requirements (anterograde transport) and to transport irreversible damaged mitochondria in the retrograde direction towards the soma to be degraded by mitophagy [28]. Faulty anterograde and retrograde transport has been shown to contribute to mitochondrial overcrowding, mislocalization and bioenergetic failure in AD [68,69]. Nine-month-old $3 \times \mathrm{Tg}$-AD mice only presented a slight decrease in the brain cortical levels of the motor protein KIF-5B (Figure 8B). However, IHC was able to induce a significant increase in both 
dynein (Figure $8 \mathrm{~A}$ ) and KIF-5B levels (Figure $8 \mathrm{~B}$ ) in $3 \times \mathrm{Tg}$-AD mice. Indeed, hypoxia has been identified as one of the few bona fide stimuli to induce a shift in the distribution of the mitochondrial network [70]. Furthermore, IHC also prevented the significant increase in syntaphilin levels (Figure $8 \mathrm{C}$ ) in $3 \times \mathrm{Tg}$-AD mice. Syntaphilin is a "static anchor" that immobilizes mitochondria, leading to the arrest of mitochondria at specific locations with high energy demands [71-73]. More recently, it was demonstrated that the release of syntaphilin removes stressed mitochondria from axons in the context of AD pathology, which contributes to the refurbishment of axonal mitochondrial quality [74]. In the face of these findings, we advocate that IHC facilitates the bidirectional transport of mitochondria to support the increase in mitochondrial biogenesis and mitophagy, culminating in enhanced mitochondrial bioenergetics in $3 \times \mathrm{Tg}$-AD mice.

Synaptic failure is assumed to be an early progressive pathological event in $\mathrm{AD}$, resulting in impaired cognitive function and memory loss, which is particularly noticeable at later stages of disease [75]. Recent breakthroughs outlined a close association between altered mitochondrial dynamics and the occurrence of synaptic lesions and degeneration in $\mathrm{AD}$ neurons [76]. In some way this is not surprising considering that synaptic terminals are high energy-demanding structures that rely on mitochondria-derived ATP to maintain functional neurotransmission [72]. Particularly, a region-specific depletion of synaptic mitochondria was observed in the brain of $\mathrm{AD}$ individuals, reinforcing the idea that defective mitochondrial transport and dynamics contributes to "synaptic starvation" and neuronal loss in AD [77]. In accordance, disruption of glutamatergic and GABAergic neurotransmission and neuronal circuits has also been extensively documented in the AD brain [78-80]. Hitherto, it was documented premature alterations in synaptic plasticity in presymptomatic three-month-old $3 \times \mathrm{Tg}-\mathrm{AD}$ mice [81]. Additionally, it was also reported that 11-month-old $3 \times \mathrm{Tg}$-AD mice exhibit alterations in synaptic integrity markers, particularly a marked decreased in PSD-95 levels in the brain cortex and a reduction in SNAP-25 levels in the hippocampus [82]. In this study, only a slight decrease in the levels of the presynaptic marker synaptotagamin-I (Figure 9B) and a significant increase in glutamate levels (Figure 9B) were detected in the brain cortex of $3 \times \mathrm{Tg}-\mathrm{AD}$. Unexpectedly, our results revealed that IHC induced a marked reduction in SNAP-25 levels (Figure 9A) and a significant increase in both GABA and glutamate levels (Figure 9D,E) in the brain cortex of WT and $3 \times \mathrm{Tg}-\mathrm{AD}$ mice. In face of this data, an exciting question has emerged: could IHC trigger a long-lasting remodeling of the synaptic structure and microenvironment to sustain neuronal and cognitive function? As a matter of fact, it was previously demonstrated that hypoxic conditioning significantly affects synaptic curvature and the percentage of synapses with presynaptic mitochondria [83]. Furthermore, IHC was also shown to be able to rescue spatial learning and memory deficits by inducing functional synaptogenesis via brain-derived neurotrophic factor (BDNF) expression [84]. Additionally, an outstanding study found that hypoxia downregulates SNAP-25, resulting in reduced vesicular docking and synaptic remodeling in order to circumvent excitotoxic neurodegeneration [85].

We demonstrated herein that IHC effectively counteracts the behavioral and cognitive abnormalities, $A \beta$ levels increase and mitochondrial bioenergetic deficits in the $3 \times \mathrm{Tg}$ - $\mathrm{AD}$ mouse model in part by targeting mitochondrial quality control axis. However, an open question from this study is how long does the beneficial impact of this non-pharmacological and non-invasive procedure last? Furthermore, a potential gap of this study pertains with the fact that sex/gender dimension was not addressed taking into account the disparities both in AD prevalence and severity between man vs woman. Therefore, further studies are warranted to advance our in-depth understanding on the (mito)protective events behind IHC phenomenon and if they hold a translational promise and whether IHC can be employed as a preventive/adjuvant therapy to counteract AD symptomatology and neuropathology in a timely manner. 


\section{Materials and Methods}

\subsection{Animals and Ethics Statements}

$3 \times$ Tg-AD mice harboring PS1/M146V, APPswe, and tauP301L transgenes, and respective WT control mice with the same genetic background (C57BL6/129S) were bred and maintained at Center for Neuroscience and Cell Biology (CNC) Animal House Facility (license $n^{\circ} 520.000 .000 .2006$, from the Portuguese Animal Welfare authorities) and provided ad libitum access to food and water and maintained under controlled light $(12 \mathrm{~h}$ day/night cycle), temperature $\left(22-24^{\circ} \mathrm{C}\right)$ and humidity (50-60\%). The 6-month-old male WT and $3 \times$ Tg-AD mice were randomly divided into two groups: (i) a conditioned and (ii) a non-conditioned control group. In the IHC paradigm, mice were submitted to a 2-week protocol previously described by Stowe and collaborators [86]. Briefly, mice were exposed to 9 hypoxic episodes over 2 weeks for either 2 or $4 \mathrm{~h}$ at either $8 \%$ or $11 \% \mathrm{O}_{2}$ as illustrated in Figure 10. Non-conditioned WT and $3 \times \mathrm{Tg}$-AD mice were handled in the same manner, but exposed only to room air. Behavioral analyses were performed around 8.5 months of age during the dark cycle. Mice were euthanized at 9 months of age by cervical dislocation and decapitation and brains were immediately removed and cortices dissected. All procedures were performed to minimize exposure to stress and suffering, in accordance with the animal welfare guidelines of the institutional animal house facility and European and Portuguese legislation (Directive 2010/63/ EU; DL113/2013, August 7).

\subsection{Behavioral Analyses}

Mice were allowed to acclimate to the behavioral testing room $1 \mathrm{~h}$ prior to each test. Behavioral tests were performed in consecutive days, by experienced observers blind to the experimental conditions.

\subsubsection{Open Field Test}

The open field test is a well-established paradigm for assaying locomotion and anxietyrelated behaviors [87]. Mice were placed individually in the center of an open field squared arena (and exploration was recorded for a 10-min period using the Stoelting ANY-MAZE video tracking system (Stoelting Co., Wood Dale, IL, USA). The total distance travelled and time spent in the center of the open-field arena were measured.

\subsubsection{MWM Test}

The MWM test was employed to assess hippocampal-dependent spatial memory as previously described by Morris [88] with slight modifications. The MWM is a swimmingbased model in which mice learn to escape a pool of water $(120 \mathrm{~cm}$ in diameter, $80 \mathrm{~cm}$ in height, filled to a depth of $60 \mathrm{~cm}$ with water at $23 \pm 2{ }^{\circ} \mathrm{C}$ ) by a hidden platform. Starting points were marked on the outside of the pool as north $(\mathrm{N})$, south (S), east (E) and west (W). Four distant cues were placed $30 \mathrm{~cm}$ above the upper edge of the water tank and the position of each symbol marked the midpoint of the perimeter of a quadrant $($ circle $=$ NE quadrant, square $=$ SE quadrant, cross $=$ SW quadrant and diamond $=$ NW quadrant). Mice were trained for 4 consecutive days with 4 trials per day. For each trial, mice were placed into the pool at one of the 4 predefined starting points in a pseudorandom order and allowed to search for the platform. Mice were guided to the platform if they were unable to reach it by themselves within $60 \mathrm{~s}$. A minimum interval of $15 \mathrm{~min}$ was given to the animals between each trial. $24 \mathrm{~h}$ after the completion of the acquisition trials, the mice received a single $60 \mathrm{~s}$ probe trial. Mice received this probe trial with the platform removed from the pool for testing the functioning of long-term memory. At this time, the percentage of time spent in the target area and the number of platform crossings were recorded with the ANY-MAZE ${ }^{\mathrm{TM}}$ video tracking system (Stoelting Co., Wood Dale, IL, USA).

\subsection{NMR Spectroscopy}

A combined extraction of polar and apolar metabolites was performed in brain cortex [89] and the aqueous phase containing the water-soluble metabolites was lyophilized. 
NMR spectra were acquired by standard methods used in our laboratory [77]. Briefly, 1H-NMR spectra were acquired at $14.1 \mathrm{~T}, 25^{\circ} \mathrm{C}$, using a Bruker Avance III $600 \mathrm{MHz}$ spectrometer equipped with a QCI cryoprobe. The spectra were acquired with solventsuppression and a sweep width of $6 \mathrm{kHz}$, using a delay of $14 \mathrm{~s}$, a water presaturation of $3 \mathrm{~s}$, a pulse angle of $45^{\circ}$, an acquisition time of $3.5 \mathrm{~s}$ and at least $128 \mathrm{scans}$. Sodium fumarate (final concentration of $1 \mathrm{mM}$ ) was used as an internal reference (6.50 ppm) to quantify the following metabolites whenever present in solution (multiplet, ppm): lactate (doublet, 1.33); alanine (doublet, 1.45); glutamate (multiplet, 2.02); GABA (triplet, 2.28); succinate (singlet, 2.39); H1- $\alpha$-glucose (doublet, 5.22). The relative areas of 1H-NMR resonances were quantified using the curve-fitting routine supplied with the NUTSproTM NMR spectral analysis program (Acorn, NMR Inc., Fremont, CA, USA.).

\subsection{Preparation of Mitochondrial Fraction}

Brain cortical mitochondria were isolated from mice by the method of Moreira and collaborators [90], using $0.02 \%$ digitonin to free mitochondria from the synaptosomal fraction. Briefly, after animal decapitation, the hippocampus was immediately separated and homogenized at $4{ }^{\circ} \mathrm{C}$ in $10 \mathrm{~mL}$ of isolation medium $(225 \mathrm{mM}$ mannitol, $75 \mathrm{mM}$ sucrose, $5 \mathrm{mM}$ HEPES, $1 \mathrm{mM}$ EGTA, $1 \mathrm{mg} / \mathrm{mL}$ BSA, pH 7.4) containing $5 \mathrm{mg}$ of the bacterial protease (Sigma-Aldrich, St. Louis, MO, USA). Single brain homogenates were brought to $30 \mathrm{~mL}$ and then centrifuged at $2500 \mathrm{rpm}$ (Sorvall Evolution RC Superspeed Refrigerated Centrifuge) for $5 \mathrm{~min}$. The pellet, including the fluffy synaptosomal layer, was resuspended in $10 \mathrm{~mL}$ of the isolation medium containing $0.02 \%$ digitonin and centrifuged at 10,000 rpm for $10 \mathrm{~min}$. The brown mitochondrial pellet without the synaptosomal layer was resuspended again in $10 \mathrm{~mL}$ of medium and centrifuged at 10,000 rpm for $5 \mathrm{~min}$. The pellet was resuspended in $10 \mathrm{~mL}$ of washing medium (225 mM mannitol, $75 \mathrm{mM}$ sucrose, 5 mM HEPES, $\mathrm{pH} 7.4$ ) and centrifuged at 10,000 rpm for $5 \mathrm{~min}$. The final mitochondrial pellet was resuspended in the washing medium and the protein amount determined by the Biuret method calibrated with BSA [91].

\subsection{Measurements of $\Delta \Psi m$}

$\Delta \Psi \mathrm{m}$ was monitored by evaluating the transmembrane distribution of the lipophilic cation $\mathrm{TPP}^{+}$(tetraphenylphosphonium) with a $\mathrm{TPP}^{+}$-selective electrode as previously described [90,92] using an Ag/AgCl-saturated electrode (Tacussel, model MI 402) as reference. $\mathrm{TPP}^{+}$uptake has been measured from the decreased $\mathrm{TPP}^{+}$concentration in the medium sensed by the electrode. The potential difference between the selective electrode and the reference electrode was measured with an electrometer and recorded continuously in a Linear 1200 recorder. The voltage response of the $\mathrm{TPP}^{+}$electrode to $\log \left[\mathrm{TPP}^{+}\right]$was linear with a slope of $59 \pm 1$, which is in a good agreement with the Nernst equation. Reactions were carried out in a chamber with magnetic stirring in $1 \mathrm{~mL}$ of the standard medium ( $100 \mathrm{mM}$ sucrose, $100 \mathrm{mM} \mathrm{KCl}, 2 \mathrm{mM} \mathrm{KH}{ }_{2} \mathrm{PO}_{4}, 5 \mathrm{mM}$ Hepes and $10 \mu \mathrm{M}$ EGTA; $\mathrm{pH} 7.4)$ containing $3 \mu \mathrm{M} \mathrm{TPP}{ }^{+}$. The $\Delta \Psi \mathrm{m}$ was estimated by the equation: $\Delta \Psi \mathrm{m}(\mathrm{mV})=59$ $\log (v / V)-59 \log (10 \Delta \mathrm{E} / 59-1) . \mathrm{v}, \mathrm{V}$, and $\Delta \mathrm{E}$ stand for mitochondrial volume, volume of the incubation medium and deflection of the electrode potential from the baseline, respectively. This equation was derived assuming that $\mathrm{TPP}^{+}$distribution between the mitochondria and the medium follows the Nernst equation, and that the law of mass conservation is applicable. A matrix volume of $1.1 \mu \mathrm{L} / \mathrm{mg}$ protein was assumed. No correction was made for the "passive" binding contribution of $\mathrm{TPP}^{+}$to the mitochondrial membranes, because the purpose of the experiments was to show relative changes in potentials rather than absolute values. As a consequence, we can anticipate a slight overestimation on $\Delta \Psi \mathrm{m}$ values. However, the overestimation is only significant at $\Delta \Psi \mathrm{m}$ values below $90 \mathrm{mV}$, therefore, far from our measurements. Mitochondria $(0.8 \mathrm{mg} / \mathrm{mL})$ were energized with $5 \mathrm{mM}$ succinate (substrate of complex II) in the presence of $2 \mu \mathrm{M}$ rotenone in order to activate the mitochondrial electron transport chain. After a steady-state distribution of $\mathrm{TPP}^{+}$had been reached (ca. $1 \mathrm{~min}$ of recording), $\Delta \Psi \mathrm{m}$ fluctuations were recorded. 


\subsection{Mitochondrial Respiration Measurements}

Oxygen consumption of mitochondria was registered polarographically with a Clark oxygen electrode connected to a suitable recorder in a thermostated water-jacketed closed chamber with magnetic stirring [93]. The reactions were carried out at $30^{\circ} \mathrm{C}$ in $1 \mathrm{~mL}$ of the standard medium (100 mM sucrose, $100 \mathrm{mM} \mathrm{KCl}, 2 \mathrm{mM} \mathrm{KH}_{2} \mathrm{PO}_{4}, 5 \mathrm{mM}$ Hepes and $10 \mu \mathrm{M}$ EGTA, pH 7.4) with $0.8 \mathrm{mg}$ of protein. States 4 and 3 respiration were initiated with $5 \mathrm{mM}$ succinate in the presence of $2 \mu \mathrm{M}$ rotenone (mitochondrial complex II energization). Exogenous ADP ( $155 \mathrm{nmol} / \mathrm{mg}$ protein) was added to initiate state 3 . In some experiments, oligomycin $(2 \mu \mathrm{g} / \mathrm{mL})$ and FCCP $(1 \mu \mathrm{M})$ were also added to inhibit passive flux through the ATP synthase and to uncouple respiration, respectively.

\subsection{Citrate Synthase Activity}

Citrate synthase activity was determined according to the method previously described by Coore and collaborators [94]. Briefly, $10 \mu \mathrm{g}$ of brain cortical homogenates were incubated at $37^{\circ} \mathrm{C}$ in a reaction buffer containing $100 \mathrm{mM}$ Tris $\mathrm{pH} 8.0$ plus $200 \mu \mathrm{M}$ Acetyl$\mathrm{CoA}, 200 \mu \mathrm{M}$ 5,5'-dithiobis-2-nitrobenzoic acid. The reaction was started by the addition of $100 \mu \mathrm{M}$ freshly-prepared oxaloacetate, and followed at $412 \mathrm{~nm}$ at $37^{\circ} \mathrm{C}(\varepsilon=13.6 \mathrm{mM} / \mathrm{cm})$.

\subsection{Determination of Mitochondrial DNA Copy Number}

RT-PCR analysis was performed to determine the mtDNA copy number of the experimental groups as described by Fuke and collaborators [95] with slight modifications. Relative quantification of mtDNA levels was determined by the ratio of the mitochondrial $\mathrm{ND} 1$ (mt-Nd1) gene to the single-copy, nuclear-encoded beta-2-microglobulin ( $\beta-2 \mathrm{MG})$ gene. Reactions were carried out in an iQ5 system (Bio-Rad), and efficiency of the reactions was determined for the selected primers using serial dilutions of DNA samples. Primer concentration and annealing temperature were optimized, and the specificity of the amplicons was determined by melting curve analysis. The reactions mixture consisted of Maxima SYBR Green qPCR Master Mix (Fermentas -Thermo Fisher Scientific, Rockford, IL, USA), sense and antisense primers (Table 2), and 20 ng of DNA. Each reaction was run in triplicate to calculate relative mtDNA copy number. $\mathrm{Ct}$ values of all samples were within the linear range. $\mathrm{Ct}$ value differences were used to quantify mtDNA copy number relative to the beta-2-microglobulin gene with the following equation: Relative copy number $=2 \Delta \mathrm{Ct}$, where $\Delta \mathrm{Ct}$ is $\mathrm{Ct} \beta 2 \mathrm{MG}-\mathrm{CtND} 1$.

Table 2. Oligonucleotides and Cycling Conditions for qPCR Amplification of ND1 and $\beta-2 \mathrm{MG}$.

\begin{tabular}{ccccc}
\hline Gene & Sequence $\left(\mathbf{5}^{\prime}-\mathbf{3}^{\prime}\right)$ & AT $\left({ }^{\circ} \mathbf{C}\right)$ & $\begin{array}{c}\text { Amplificon } \\
\text { Size (bp) }\end{array}$ & C \\
\hline ND1 & $\begin{array}{c}\text { Sense: GAG CCC TAC GAG CCG TTG CC } \\
\text { Antisense: GCG AATG GTC CTG CGG CGT A }\end{array}$ & 58 & 271 & 30 \\
\hline$\beta-2 M G$ & $\begin{array}{c}\text { Sense: GCG TGG GAG GAG CAT CAG GG } \\
\text { Antisense: CTC ATC ACC ACC CCG GGG ACT }\end{array}$ & 58 & 264 & 30 \\
\hline
\end{tabular}

Abbreviations: AT-annealing temperature; $\mathrm{C}-$ Number of cycles of amplification.

\subsection{Western Blot Analysis}

Brain cortical samples were homogenized in ice-cold lysis buffer $(20 \mathrm{mM}$ Tris- $\mathrm{HCl} \mathrm{pH}$ 7.5, $150 \mathrm{mM} \mathrm{NaCl}, 1 \mathrm{mM} \mathrm{Na}{ }_{2}$ EDTA, $1 \mathrm{mM}$ EGTA, $1 \%$ Triton, $2.5 \mathrm{mM}$ sodium pyrophosphate, $1 \mathrm{mM} \beta$-glycerophosphate, $1 \mathrm{mM} \mathrm{Na}_{3} \mathrm{VO}_{4}, 1 \mu \mathrm{g} / \mathrm{mL}$ leupeptin) supplemented with $0.1 \mathrm{M}$ phenylmethanesulfonylfluoride (PMSF), $0.2 \mathrm{M}$ dithiothreitol (DTT) and protease and phosphatase inhibitors cocktails (Roche Applied Science, Indianapolis, IN, USA). The homogenates were frozen and defrozen 3 times to favor disruption, centrifuged at 14,000 rpm (Eppendorf centrifuge 5415C) for $10 \mathrm{~min}$ at $4{ }^{\circ} \mathrm{C}$ and the supernatant collected and stored at $-80{ }^{\circ} \mathrm{C}$. Protein concentration was determined by the bicinchoninic acid (BCA) protein assay using the BCA kit (Pierce Thermo Fisher Scientific, Rockford, IL. USA). 
Equivalent amounts of protein $(40 \mu \mathrm{g})$ were resolved by electrophoresis in $8-15 \%$ sodium dodecyl sulfate (SDS)-polyacrylamide gels and transferred to polyvinylidene fluoride (Millipore, Billerica, MA, USA) membranes. Non-specific binding was blocked by incubation with blocking buffer [10\% BSA in Tris-buffered saline (TBS)] for $1 \mathrm{~h}$ at room temperature, with gentle agitation. The blots were subsequently incubated overnight at $4{ }^{\circ} \mathrm{C}$ with gentle agitation with the specific primary antibodies. Blots were washed 3 times (5 min each), with TBS containing $0.1 \%$ Tween (TBS-T) and then were incubated with the secondary antibodies for $1 \mathrm{~h}$ at room temperature with gentle agitation. After membrane incubation with enhanced chemifluorescence reagent (ECF), images were obtained in a VersaDoc Imaging System (Bio-Rad, Hercules, CA, USA) and the density of protein bands calculated using the Quantity OneProgram (Bio-Rad, Hercules, CA, USA). The antibodies used are listed in Table 3.

Table 3. List of primary and secondary antibodies.

\begin{tabular}{|c|c|c|c|c|}
\hline Antibody & $\begin{array}{l}\text { Catalog } \\
\text { Number }\end{array}$ & Supplier & $\begin{array}{c}\text { Host } \\
\text { Specie }\end{array}$ & Dilution \\
\hline $\mathrm{A} \beta(6 \mathrm{E} 10)$ & SIG-39300 & Covance & Mouse & 1:1000 \\
\hline DRP1 & 611113 & BD Biosciences & Mouse & 1:1000 \\
\hline Dynein & sc-13524 & $\begin{array}{c}\text { Santa Cruz } \\
\text { Biotechnology }\end{array}$ & Mouse & $1: 500$ \\
\hline Fis1 & $\begin{array}{l}\text { IMG- } \\
5113 \mathrm{~A}\end{array}$ & ImGenex & Rabbit & $1: 750$ \\
\hline KIF-5B & Ab5629 & Abcam & Rabbit & 1:1000 \\
\hline LAMP-1 & 3243 & Cell Signaling & Rabbit & $1: 500$ \\
\hline LC3B (D11) & 3868 & Cell Signaling & Rabbit & 1:1000 \\
\hline Mnf-1 & sc- 50330 & $\begin{array}{c}\text { Santa Cruz } \\
\text { Biotechnology }\end{array}$ & Rabbit & $1: 1000$ \\
\hline Mnf-2 & sc- 100560 & $\begin{array}{c}\text { Santa Cruz } \\
\text { Biotechnology }\end{array}$ & Mouse & 1:1000 \\
\hline OPA-1 & 612607 & BD Biosciences & Mouse & $1: 1000$ \\
\hline Parkin & 2132 & Cell Signaling & Rabbit & 1:1000 \\
\hline PINK-1 & sc-517353 & $\begin{array}{c}\text { Santa Cruz } \\
\text { Biotechnology }\end{array}$ & Mouse & $1: 500$ \\
\hline PSD-95 & D27E11 & Cell Signaling & Rabbit & $1: 1000$ \\
\hline $\mathrm{p}^{\text {Ser616-DRP1 }}$ & 3455 & Cell Signaling & Rabbit & 1:1000 \\
\hline SNAP-25 & S5187 & Sigma Aldrich & Mouse & 1:1000 \\
\hline Synaptotagmin-I & sc-136480 & $\begin{array}{c}\text { Santa Cruz } \\
\text { Biotechnology }\end{array}$ & Mouse & 1:1000 \\
\hline Syntaphilin & sc-365606 & $\begin{array}{c}\text { Santa Cruz } \\
\text { Biotechnology }\end{array}$ & Mouse & $1: 500$ \\
\hline Tau (AT8) & Mn1020 & Thermo Scientific & Mouse & $1: 750$ \\
\hline TFAM & sc-30965 & $\begin{array}{c}\text { Santa Cruz } \\
\text { Biotechnology }\end{array}$ & Goat & $1: 750$ \\
\hline TOM20 & sc-11415 & $\begin{array}{c}\text { Santa Cruz } \\
\text { Biotechnology }\end{array}$ & Rabbit & $1: 1000$ \\
\hline
\end{tabular}


Table 3. Cont.

\begin{tabular}{ccccc}
\hline Antibody & $\begin{array}{c}\text { Catalog } \\
\text { Number }\end{array}$ & Supplier & $\begin{array}{c}\text { Host } \\
\text { Specie }\end{array}$ & Dilution \\
\hline$\beta$-Actin & A5441 & Sigma Aldrich & Mouse & $1: 5000$ \\
\hline $\begin{array}{c}\text { Mouse IgG alkaline } \\
\text { phosphatase conjugate }\end{array}$ & NIF1316 & $\begin{array}{c}\text { Amersham } \\
\text { Pharmacia Biotech }\end{array}$ & Goat & $1: 10,000$ \\
\hline $\begin{array}{c}\text { Rabbit IgG alkaline } \\
\text { phosphatase conjugate }\end{array}$ & NIF1317 & $\begin{array}{c}\text { Amersham } \\
\text { Pharmacia Biotech }\end{array}$ & Goat & $1: 10,000$ \\
\hline
\end{tabular}

\subsection{Immuno-Dot-Blot Assay}

$\mathrm{A} \beta$ levels were detected using $6 \mathrm{E} 10$ antibody in non-denaturing immuno-dot blot conditions. Briefly, after PVDF membrane activation, $20 \mu \mathrm{g}$ of brain cortical homogenates, in a final volume of $5 \mu \mathrm{L}$, were placed in dots in specific zones of the membrane. As soon as the dots were dried, the non-specific binding reactions were blocked using $10 \%$ BSA for $1 \mathrm{~h}$ at room temperature. Thereafter, membranes were incubated with the respective primary antibody overnight at $4{ }^{\circ} \mathrm{C}$. Subsequently, membranes were washed 3 times with TBS-T and incubated with the secondary antibody for $1 \mathrm{~h}$ at room temperature. Then, after 3 washes with TBS-T, membranes were incubated with ECF and protein dots visualized using the VersaDoc Imaging System (Bio-Rad, Hercules, CA, USA) and the density of protein dots calculated using the Quantity OneProgram. The antibodies used are listed in Table 3.

\subsection{Statistical Analysis}

Data regarding mitochondrial bioenergetic parameters are presented as mean \pm SEM of the indicated number of animals. All other data are expressed as median \pm interquartile range. Statistical significance was determined using the one-way ANOVA test for multiple comparisons, followed by the posthoc Tukey-Kramer test with the program GraphPad Prism 6 (GraphPad Software, San Diego, CA, USA). Statistical significance was noted at $p<0.05$.

Author Contributions: Conceptualization, S.C.C.; planning the experimental approach, S.C.C.; methodology and data analysis, S.C.C., N.J.M., M.G.A., and P.F.O.; data discussion; S.C.C. and P.I.M.; writing—original draft preparation, S.C.C.; writing—review \& editing, P.I.M., funding acquisition, P.I.M., M.G.A., and P.F.O. All authors have read and agreed to the published version of the manuscript.

Funding: This work was financed by the European Regional Development Fund (ERDF), through the Centro 2020 Regional Operational Programme (Projects Healthy Aging2020) by COMPETE 2020-Operational Programme for Competitiveness and Internationalisation and Portuguese national funds via FCT-Fundação para a Ciência e a Tecnologia, under projects UIDB/04539/2020, PEst-OE/SAU/UI0215/2019 and UID/QUI/00062/2019 and by Post-Doctoral Researcher Contract DL57/2016 \#SFRH/BPD/109822/2015 to S.C.Correia.

Institutional Review Board Statement: The study was conducted upon the ethical approval by the Animal Welfare Committee of the Center for Neuroscience and Cell Biology and Faculty of Medicine, University of Coimbra (Project ORBEA_61_2013/24072013).

Informed Consent Statement: Not applicable.

Data Availability Statement: The data presented in this study are available in the published article.

Acknowledgments: We are grateful to Rodrigo Cunha (CNC and Laboratory of Biochemistry, Faculty of Medicine, University of Coimbra, Coimbra, Portugal) for his valuable help with the behavioral tests.

Conflicts of Interest: The authors declare no conflict of interest. 


\section{References}

1. Hickman, R.A.; Faustin, A.; Wisniewski, T. Alzheimer Disease and Its Growing Epidemic: Risk Factors, Biomarkers, and the Urgent Need for Therapeutics. Neurol. Clin. 2016, 34, 941-953. [CrossRef] [PubMed]

2. Collaborators, G.B.D.D. Global, regional, and national burden of Alzheimer's disease and other dementias, 1990-2016: A systematic analysis for the Global Burden of Disease Study 2016. Lancet Neurol. 2019, 18, 88-106. [CrossRef]

3. Mielke, M.M.; Vemuri, P.; Rocca, W.A. Clinical epidemiology of Alzheimer's disease: Assessing sex and gender differences. Clin. Epidemiol. 2014, 6, 37-48. [CrossRef] [PubMed]

4. Querfurth, H.W.; LaFerla, F.M. Alzheimer's disease. N. Engl. J. Med. 2010, 362, 329-344. [CrossRef] [PubMed]

5. Jack, C.R., Jr.; Bennett, D.A.; Blennow, K.; Carrillo, M.C.; Dunn, B.; Haeberlein, S.B.; Holtzman, D.M.; Jagust, W.; Jessen, F.; Karlawish, J.; et al. NIA-AA Research Framework: Toward a biological definition of Alzheimer's disease. Alzheimers Dement. J. Alzheimers Assoc. 2018, 14, 535-562. [CrossRef]

6. Braak, H.; Braak, E. Staging of Alzheimer's disease-related neurofibrillary changes. Neurobiol. Aging 1995, 16, 271-278. [CrossRef]

7. Aisen, P.S.; Cummings, J.; Jack, C.R., Jr.; Morris, J.C.; Sperling, R.; Frolich, L.; Jones, R.W.; Dowsett, S.A.; Matthews, B.R.; Raskin, J.; et al. On the path to 2025: Understanding the Alzheimer's disease continuum. Alzheimers Res. Ther. 2017, 9, 60. [CrossRef]

8. Masters, C.L.; Bateman, R.; Blennow, K.; Rowe, C.C.; Sperling, R.A.; Cummings, J.L. Alzheimer's disease. Nat. Rev. Dis. Primers 2015, 1, 15056. [CrossRef]

9. DeTure, M.A.; Dickson, D.W. The neuropathological diagnosis of Alzheimer's disease. Mol. Neurodegener. 2019, 14, 32. [CrossRef]

10. Cardoso, S.; Carvalho, C.; Correia, S.C.; Seica, R.M.; Moreira, P.I. Alzheimer's Disease: From Mitochondrial Perturbations to Mitochondrial Medicine. Brain Pathol. 2016, 26, 632-647. [CrossRef]

11. Dezfulian, C.; Garrett, M.; Gonzalez, N.R. Clinical application of preconditioning and postconditioning to achieve neuroprotection. Transl. Stroke Res. 2013, 4, 19-24. [CrossRef] [PubMed]

12. Leak, R.K. Conditioning Against the Pathology of Parkinson's disease. Cond. Med. 2018, 1, 143-162. [PubMed]

13. Wang, Y.; Reis, C.; Applegate, R., 2nd; Stier, G.; Martin, R.; Zhang, J.H. Ischemic conditioning-induced endogenous brain protection: Applications pre-, per- or post-stroke. Exp. Neurol. 2015, 272, 26-40. [CrossRef] [PubMed]

14. Calabrese, E.J.; Agathokleous, E. Building Biological Shields via Hormesis. Trends Pharm. Sci. 2019, 40, 8-10. [CrossRef]

15. Vinciguerra, A.; Cuomo, O.; Cepparulo, P.; Anzilotti, S.; Brancaccio, P.; Sirabella, R.; Guida, N.; Annunziato, L.; Pignataro, G. Models and methods for conditioning the ischemic brain. J. Neurosci. Methods 2018, 310, 63-74. [CrossRef]

16. Manukhina, E.B.; Goryacheva, A.V.; Barskov, I.V.; Viktorov, I.V.; Guseva, A.A.; Pshennikova, M.G.; Khomenko, I.P.; Mashina, S.Y.; Pokidyshev, D.A.; Malyshev, I.Y. Prevention of neurodegenerative damage to the brain in rats in experimental Alzheimer's disease by adaptation to hypoxia. Neurosci. Behav. Physiol. 2010, 40, 737-743. [CrossRef]

17. Boengler, K.; Heusch, G.; Schulz, R. Mitochondria in postconditioning. Antioxid. Redox Signal. 2011, 14, 863-880. [CrossRef]

18. Boengler, K.; Lochnit, G.; Schulz, R. Mitochondria "THE" target of myocardial conditioning. Am. J. Physiol. Heart Circ. Physiol. 2018, 315, H1215-H1231. [CrossRef]

19. Correia, S.C.; Cardoso, S.; Santos, R.X.; Carvalho, C.; Santos, M.S.; Perry, G.; Smith, M.A.; Moreira, P.I. New insights into the mechanisms of mitochondrial preconditioning-triggered neuroprotection. Curr. Pharm. Des. 2011, 17, 3381-3389. [CrossRef]

20. Oddo, S.; Caccamo, A.; Shepherd, J.D.; Murphy, M.P.; Golde, T.E.; Kayed, R.; Metherate, R.; Mattson, M.P.; Akbari, Y.; LaFerla, F.M. Triple-transgenic model of Alzheimer's disease with plaques and tangles: Intracellular Abeta and synaptic dysfunction. Neuron 2003, 39, 409-421. [CrossRef]

21. Correia, S.C.; Santos, R.X.; Carvalho, C.; Cardoso, S.; Candeias, E.; Santos, M.S.; Oliveira, C.R.; Moreira, P.I. Insulin signaling, glucose metabolism and mitochondria: Major players in Alzheimer's disease and diabetes interrelation. Brain Res. 2012, 1441, 64-78. [CrossRef] [PubMed]

22. Cunnane, S.C.; Trushina, E.; Morland, C.; Prigione, A.; Casadesus, G.; Andrews, Z.B.; Beal, M.F.; Bergersen, L.H.; Brinton, R.D.; de la Monte, S.; et al. Brain energy rescue: An emerging therapeutic concept for neurodegenerative disorders of ageing. Nat. Rev. Drug Discov. 2020, 19, 609-633. [CrossRef] [PubMed]

23. Daulatzai, M.A. Cerebral hypoperfusion and glucose hypometabolism: Key pathophysiological modulators promote neurodegeneration, cognitive impairment, and Alzheimer's disease. J. Neurosci. Res. 2017, 95, 943-972. [CrossRef] [PubMed]

24. Chen, H.; Chan, D.C. Mitochondrial dynamics—fusion, fission, movement, and mitophagy-In neurodegenerative diseases. Hum. Mol. Genet. 2009, 18, R169-R176. [CrossRef] [PubMed]

25. Seager, R.; Lee, L.; Henley, J.M.; Wilkinson, K.A. Mechanisms and roles of mitochondrial localisation and dynamics in neuronal function. Neuronal Signal. 2020, 4, NS20200008. [CrossRef] [PubMed]

26. Liang, Y. Emerging Concepts and Functions of Autophagy as a Regulator of Synaptic Components and Plasticity. Cells 2019, 8, 34. [CrossRef] [PubMed]

27. Stavoe, A.K.H.; Holzbaur, E.L.F. Autophagy in Neurons. Annu. Rev. Cell Dev. Biol. 2019, 35, 477-500. [CrossRef] [PubMed]

28. Correia, S.C.; Perry, G.; Moreira, P.I. Mitochondrial traffic jams in Alzheimer's disease-pinpointing the roadblocks. Biochim. Biophys. Acta 2016, 1862, 1909-1917. [CrossRef]

29. Zheng, Y.R.; Zhang, X.N.; Chen, Z. Mitochondrial transport serves as a mitochondrial quality control strategy in axons: Implications for central nervous system disorders. CNS Neurosci. Ther. 2019, 25, 876-886. [CrossRef]

30. Belfiore, R.; Rodin, A.; Ferreira, E.; Velazquez, R.; Branca, C.; Caccamo, A.; Oddo, S. Temporal and regional progression of Alzheimer's disease-like pathology in 3xTg-AD mice. Aging Cell 2019, 18, e12873. [CrossRef] 
31. Meng, S.X.; Wang, B.; Li, W.T. Intermittent hypoxia improves cognition and reduces anxiety-related behavior in APP/PS1 mice. Brain Behav. 2020, 10, e01513. [CrossRef] [PubMed]

32. Wang, H.; Shi, X.; Schenck, H.; Hall, J.R.; Ross, S.E.; Kline, G.P.; Chen, S.; Mallet, R.T.; Chen, P. Intermittent Hypoxia Training for Treating Mild Cognitive Impairment: A Pilot Study. Am. J. Alzheimers Dis. Dement. 2020, 35, 1533317519896725. [CrossRef] [PubMed]

33. Pascoal, T.A.; Mathotaarachchi, S.; Mohades, S.; Benedet, A.L.; Chung, C.O.; Shin, M.; Wang, S.; Beaudry, T.; Kang, M.S.; Soucy, J.P.; et al. Amyloid-beta and hyperphosphorylated tau synergy drives metabolic decline in preclinical Alzheimer's disease. Mol. Psychiatry 2017, 22, 306-311. [CrossRef] [PubMed]

34. Pascoal, T.A.; Mathotaarachchi, S.; Shin, M.; Benedet, A.L.; Mohades, S.; Wang, S.; Beaudry, T.; Kang, M.S.; Soucy, J.P.; Labbe, A.; et al. Synergistic interaction between amyloid and tau predicts the progression to dementia. Alzheimers Dement. J. Alzheimers Assoc. 2017, 13, 644-653. [CrossRef]

35. Rhein, V.; Song, X.; Wiesner, A.; Ittner, L.M.; Baysang, G.; Meier, F.; Ozmen, L.; Bluethmann, H.; Drose, S.; Brandt, U.; et al. Amyloid-beta and tau synergistically impair the oxidative phosphorylation system in triple transgenic Alzheimer's disease mice. Proc. Natl. Acad. Sci. USA 2009, 106, 20057-20062. [CrossRef]

36. Shiota, S.; Takekawa, H.; Matsumoto, S.E.; Takeda, K.; Nurwidya, F.; Yoshioka, Y.; Takahashi, F.; Hattori, N.; Tabira, T.; Mochizuki, H.; et al. Chronic intermittent hypoxia/reoxygenation facilitate amyloid-beta generation in mice. J. Alzheimers Dis. JAD 2013, 37, 325-333. [CrossRef]

37. Ashok, B.S.; Ajith, T.A.; Sivanesan, S. Hypoxia-inducible factors as neuroprotective agent in Alzheimer's disease. Clin. Exp. Pharmacol. Physiol. 2017, 44, 327-334. [CrossRef]

38. Zhang, F.; Niu, L.; Li, S.; Le, W. Pathological Impacts of Chronic Hypoxia on Alzheimer's Disease. ACS Chem. Neurosci. 2019, 10, 902-909. [CrossRef]

39. Azari, N.P.; Pettigrew, K.D.; Schapiro, M.B.; Haxby, J.V.; Grady, C.L.; Pietrini, P.; Salerno, J.A.; Heston, L.L.; Rapoport, S.I.; Horwitz, B. Early detection of Alzheimer's disease: A statistical approach using positron emission tomographic data. J. Cereb. Blood Flow Metab. 1993, 13, 438-447. [CrossRef]

40. Bubber, P.; Haroutunian, V.; Fisch, G.; Blass, J.P.; Gibson, G.E. Mitochondrial abnormalities in Alzheimer brain: Mechanistic implications. Ann. Neurol. 2005, 57, 695-703. [CrossRef]

41. Mastrogiacomo, F.; Bergeron, C.; Kish, S.J. Brain alpha-ketoglutarate dehydrogenase complex activity in Alzheimer's disease. J. Neurochem. 1993, 61, 2007-2014. [CrossRef]

42. Bosetti, F.; Brizzi, F.; Barogi, S.; Mancuso, M.; Siciliano, G.; Tendi, E.A.; Murri, L.; Rapoport, S.I.; Solaini, G. Cytochrome c oxidase and mitochondrial F1F0-ATPase (ATP synthase) activities in platelets and brain from patients with Alzheimer's disease. Neurobiol. Aging 2002, 23, 371-376. [CrossRef]

43. Cardoso, S.M.; Proenca, M.T.; Santos, S.; Santana, I.; Oliveira, C.R. Cytochrome c oxidase is decreased in Alzheimer's disease platelets. Neurobiol. Aging 2004, 25, 105-110. [CrossRef]

44. Kish, S.J.; Bergeron, C.; Rajput, A.; Dozic, S.; Mastrogiacomo, F.; Chang, L.J.; Wilson, J.M.; DiStefano, L.M.; Nobrega, J.N. Brain cytochrome oxidase in Alzheimer's disease. J. Neurochem. 1992, 59, 776-779. [CrossRef] [PubMed]

45. Valla, J.; Schneider, L.; Niedzielko, T.; Coon, K.D.; Caselli, R.; Sabbagh, M.N.; Ahern, G.L.; Baxter, L.; Alexander, G.; Walker, D.G.; et al. Impaired platelet mitochondrial activity in Alzheimer's disease and mild cognitive impairment. Mitochondrion 2006, 6, 323-330. [CrossRef] [PubMed]

46. Eckert, A.; Schmitt, K.; Gotz, J. Mitochondrial dysfunction-the beginning of the end in Alzheimer's disease? Separate and synergistic modes of tau and amyloid-beta toxicity. Alzheimers Res. Ther. 2011, 3, 15. [CrossRef]

47. Carvalho, C.; Cardoso, S.; Correia, S.C.; Santos, R.X.; Santos, M.S.; Baldeiras, I.; Oliveira, C.R.; Moreira, P.I. Metabolic alterations induced by sucrose intake and Alzheimer's disease promote similar brain mitochondrial abnormalities. Diabetes 2012, 61, 1234-1242. [CrossRef]

48. Chen, J.; Liao, W.; Gao, W.; Huang, J.; Gao, Y. Intermittent hypoxia protects cerebral mitochondrial function from calcium overload. Acta Neurol. Belg. 2013, 113, 507-513. [CrossRef]

49. Ju, X.; Mallet, R.T.; Downey, H.F.; Metzger, D.B.; Jung, M.E. Intermittent hypoxia conditioning protects mitochondrial cytochrome c oxidase of rat cerebellum from ethanol withdrawal stress. J. Appl. Physiol. 2012, 112, 1706-1714. [CrossRef]

50. Baloyannis, S.J. Mitochondrial alterations in Alzheimer's disease. J. Alzheimers Dis. JAD 2006, 9, 119-126. [CrossRef]

51. Hirai, K.; Aliev, G.; Nunomura, A.; Fujioka, H.; Russell, R.L.; Atwood, C.S.; Johnson, A.B.; Kress, Y.; Vinters, H.V.; Tabaton, M.; et al. Mitochondrial abnormalities in Alzheimer's disease. J. Neurosci. 2001, 21, 3017-3023. [CrossRef]

52. Gao, J.; Wang, L.; Liu, J.; Xie, F.; Su, B.; Wang, X. Abnormalities of Mitochondrial Dynamics in Neurodegenerative Diseases. Antioxidants 2017, 6, 25. [CrossRef] [PubMed]

53. Wai, T.; Langer, T. Mitochondrial Dynamics and Metabolic Regulation. Trends Endocrinol. Metab. TEM 2016, $27,105-117$. [CrossRef] [PubMed]

54. Berman, S.B.; Pineda, F.J.; Hardwick, J.M. Mitochondrial fission and fusion dynamics: The long and short of it. Cell Death Differ. 2008, 15, 1147-1152. [CrossRef]

55. Wang, X.; Su, B.; Lee, H.G.; Li, X.; Perry, G.; Smith, M.A.; Zhu, X. Impaired balance of mitochondrial fission and fusion in Alzheimer's disease. J. Neurosci. 2009, 29, 9090-9103. [CrossRef] [PubMed] 
56. Gan, X.; Huang, S.; Wu, L.; Wang, Y.; Hu, G.; Li, G.; Zhang, H.; Yu, H.; Swerdlow, R.H.; Chen, J.X.; et al. Inhibition of ERK-DLP1 signaling and mitochondrial division alleviates mitochondrial dysfunction in Alzheimer's disease cybrid cell. Biochim. Et Biophys. Acta 2014, 1842, 220-231. [CrossRef]

57. Espino de la Fuente-Munoz, C.; Rosas-Lemus, M.; Moreno-Castilla, P.; Bermudez-Rattoni, F.; Uribe-Carvajal, S.; Arias, C. AgeDependent Decline in Synaptic Mitochondrial Function Is Exacerbated in Vulnerable Brain Regions of Female 3xTg-AD Mice. Int. J. Mol. Sci. 2020, 21, 8727. [CrossRef]

58. Das, R.; Chakrabarti, O. Mitochondrial hyperfusion: A friend or a foe. Biochem. Soc. Trans. 2020, 48, 631-644. [CrossRef]

59. Chen, H.; McCaffery, J.M.; Chan, D.C. Mitochondrial fusion protects against neurodegeneration in the cerebellum. Cell 2007, 130, 548-562. [CrossRef]

60. Qin, W.; Haroutunian, V.; Katsel, P.; Cardozo, C.P.; Ho, L.; Buxbaum, J.D.; Pasinetti, G.M. PGC-1alpha expression decreases in the Alzheimer disease brain as a function of dementia. Arch. Neurol. 2009, 66, 352-361. [CrossRef]

61. Sheng, B.; Wang, X.; Su, B.; Lee, H.G.; Casadesus, G.; Perry, G.; Zhu, X. Impaired mitochondrial biogenesis contributes to mitochondrial dysfunction in Alzheimer's disease. J. Neurochem. 2012, 120, 419-429. [CrossRef] [PubMed]

62. Gutsaeva, D.R.; Carraway, M.S.; Suliman, H.B.; Demchenko, I.T.; Shitara, H.; Yonekawa, H.; Piantadosi, C.A. Transient hypoxia stimulates mitochondrial biogenesis in brain subcortex by a neuronal nitric oxide synthase-dependent mechanism. J. Neurosci. 2008, 28, 2015-2024. [CrossRef]

63. Pickles, S.; Vigie, P.; Youle, R.J. Mitophagy and Quality Control Mechanisms in Mitochondrial Maintenance. Curr. Biol. CB 2018, 28, R170-R185. [CrossRef] [PubMed]

64. Ye, X.; Sun, X.; Starovoytov, V.; Cai, Q. Parkin-mediated mitophagy in mutant hAPP neurons and Alzheimer's disease patient brains. Hum. Mol. Genet. 2015, 24, 2938-2951. [CrossRef] [PubMed]

65. Martin-Maestro, P.; Gargini, R.; Perry, G.; Avila, J.; Garcia-Escudero, V. PARK2 enhancement is able to compensate mitophagy alterations found in sporadic Alzheimer's disease. Hum. Mol. Genet. 2016, 25, 792-806. [CrossRef] [PubMed]

66. Martin-Maestro, P.; Gargini, R.; Sproul, A.A.; Garcia, E.; Anton, L.C.; Noggle, S.; Arancio, O.; Avila, J.; Garcia-Escudero, V. Mitophagy Failure in Fibroblasts and iPSC-Derived Neurons of Alzheimer's Disease-Associated Presenilin 1 Mutation. Front. Mol. Neurosci. 2017, 10, 291. [CrossRef]

67. Zhou, M.; Xia, Z.Y.; Lei, S.Q.; Leng, Y.; Xue, R. Role of mitophagy regulated by Parkin/DJ-1 in remote ischemic postconditioninginduced mitigation of focal cerebral ischemia-reperfusion. Eur. Rev. Med Pharmacol. Sci. 2015, 19, 4866-4871. [PubMed]

68. Correia, S.C.; Santos, R.X.; Cardoso, S.; Carvalho, C.; Candeias, E.; Duarte, A.I.; Placido, A.I.; Santos, M.S.; Moreira, P.I. Alzheimer disease as a vascular disorder: Where do mitochondria fit? Exp. Gerontol. 2012, 47, 878-886. [CrossRef]

69. Trimmer, P.A.; Borland, M.K. Differentiated Alzheimer's disease transmitochondrial cybrid cell lines exhibit reduced organelle movement. Antioxid. Redox Signal. 2005, 7, 1101-1109. [CrossRef]

70. Thomas, L.W.; Ashcroft, M. Exploring the molecular interface between hypoxia-inducible factor signalling and mitochondria. Cell. Mol. Life Sci. CMLS 2019, 76, 1759-1777. [CrossRef]

71. Lin, M.Y.; Sheng, Z.H. Regulation of mitochondrial transport in neurons. Exp. Cell Res. 2015, 334, 35-44. [CrossRef] [PubMed]

72. Sheng, Z.H. Mitochondrial trafficking and anchoring in neurons: New insight and implications. J. Cell Biol. 2014, 204, 1087-1098. [CrossRef] [PubMed]

73. Sheng, Z.H.; Cai, Q. Mitochondrial transport in neurons: Impact on synaptic homeostasis and neurodegeneration. Nat. Rev. Neurosci. 2012, 13, 77-93. [CrossRef] [PubMed]

74. Lin, M.Y.; Cheng, X.T.; Tammineni, P.; Xie, Y.; Zhou, B.; Cai, Q.; Sheng, Z.H. Releasing Syntaphilin Removes Stressed Mitochondria from Axons Independent of Mitophagy under Pathophysiological Conditions. Neuron 2017, 94, 595-610.e6. [CrossRef]

75. Chen, Y.; Fu, A.K.Y.; Ip, N.Y. Synaptic dysfunction in Alzheimer's disease: Mechanisms and therapeutic strategies. Pharmacol. Ther. 2019, 195, 186-198. [CrossRef]

76. Tang, J.; Oliveros, A.; Jang, M.H. Dysfunctional Mitochondrial Bioenergetics and Synaptic Degeneration in Alzheimer Disease. Int. Neurourol. J. 2019, 23, S5-10. [CrossRef]

77. Rato, L.; Alves, M.G.; Dias, T.R.; Lopes, G.; Cavaco, J.E.; Socorro, S.; Oliveira, P.F. High-energy diets may induce a pre-diabetic state altering testicular glycolytic metabolic profile and male reproductive parameters. Andrology 2013, 1, 495-504. [CrossRef]

78. Calvo-Flores Guzman, B.; Vinnakota, C.; Govindpani, K.; Waldvogel, H.J.; Faull, R.L.M.; Kwakowsky, A. The GABAergic system as a therapeutic target for Alzheimer's disease. J. Neurochem. 2018, 146, 649-669. [CrossRef]

79. Conway, M.E. Alzheimer's disease: Targeting the glutamatergic system. Biogerontology 2020, 21, 257-274. [CrossRef]

80. Tiwari, V.; Patel, A.B. Impaired glutamatergic and GABAergic function at early age in AbetaPPswe-PS1dE9 mice: Implications for Alzheimer's disease. J. Alzheimers Dis. JAD 2012, 28, 765-769. [CrossRef]

81. Clark, J.K.; Furgerson, M.; Crystal, J.D.; Fechheimer, M.; Furukawa, R.; Wagner, J.J. Alterations in synaptic plasticity coincide with deficits in spatial working memory in presymptomatic 3xTg-AD mice. Neurobiol. Learn. Mem. 2015, 125, 152-162. [CrossRef] [PubMed]

82. Carvalho, C.; Santos, M.S.; Oliveira, C.R.; Moreira, P.I. Alzheimer's disease and type 2 diabetes-related alterations in brain mitochondria, autophagy and synaptic markers. Biochim. Biophys. Acta 2015, 1852, 1665-1675. [CrossRef] [PubMed]

83. Liu, Y.; Sun, Z.; Sun, S.; Duan, Y.; Shi, J.; Qi, Z.; Meng, R.; Sun, Y.; Zeng, X.; Chui, D.; et al. Effects of hypoxic preconditioning on synaptic ultrastructure in mice. Synapse 2015, 69, 7-14. [CrossRef] [PubMed] 
84. Tsai, Y.W.; Yang, Y.R.; Sun, S.H.; Liang, K.C.; Wang, R.Y. Post ischemia intermittent hypoxia induces hippocampal neurogenesis and synaptic alterations and alleviates long-term memory impairment. J. Cereb. Blood Flow Metab. 2013, 33, 764-773. [CrossRef] [PubMed]

85. Biswal, S.; Das, D.; Barhwal, K.; Kumar, A.; Nag, T.C.; Thakur, M.K.; Hota, S.K.; Kumar, B. Epigenetic Regulation of SNAP25 Prevents Progressive Glutamate Excitotoxicty in Hypoxic CA3 Neurons. Mol. Neurobiol. 2017, 54, 6133-6147. [CrossRef]

86. Stowe, A.M.; Altay, T.; Freie, A.B.; Gidday, J.M. Repetitive hypoxia extends endogenous neurovascular protection for stroke. Ann. Neurol. 2011, 69, 975-985. [CrossRef]

87. Kraeuter, A.K.; Guest, P.C.; Sarnyai, Z. The Open Field Test for Measuring Locomotor Activity and Anxiety-Like Behavior. Methods Mol. Biol. 2019, 1916, 99-103. [CrossRef]

88. Morris, R. Developments of a water-maze procedure for studying spatial learning in the rat. J. Neurosci. Methods 1984, 11, 47-60. [CrossRef]

89. Alves, M.G.; Oliveira, P.J.; Carvalho, R.A. Substrate selection in hearts subjected to ischemia/reperfusion: Role of cardioplegic solutions and gender. NMR Biomed. 2011, 24, 1029-1037. [CrossRef]

90. Moreira, P.I.; Santos, M.S.; Moreno, A.; Oliveira, C. Amyloid beta-peptide promotes permeability transition pore in brain mitochondria. Biosci. Rep. 2001, 21, 789-800. [CrossRef]

91. Gornall, A.G.; Bardawill, C.J.; David, M.M. Determination of serum proteins by means of the biuret reaction. J. Biol. Chem. 1949, 177, 751-766. [PubMed]

92. Correia, S.C.; Santos, R.X.; Santos, M.S.; Casadesus, G.; Lamanna, J.C.; Perry, G.; Smith, M.A.; Moreira, P.I. Mitochondrial abnormalities in a streptozotocin-induced rat model of sporadic Alzheimer's disease. Curr. Alzheimer Res. 2013, 10, 406-419. [CrossRef] [PubMed]

93. Silva, A.M.; Oliveira, P.J. Evaluation of Respiration with Clark-Type Electrode in Isolated Mitochondria and Permeabilized Animal Cells. Methods Mol. Biol. 2018, 1782, 7-29. [CrossRef] [PubMed]

94. Coore, H.G.; Denton, R.M.; Martin, B.R.; Randle, P.J. Regulation of adipose tissue pyruvate dehydrogenase by insulin and other hormones. Biochem. J. 1971, 125, 115-127. [CrossRef] [PubMed]

95. Fuke, S.; Kubota-Sakashita, M.; Kasahara, T.; Shigeyoshi, Y.; Kato, T. Regional variation in mitochondrial DNA copy number in mouse brain. Biochim. Biophys. Acta 2011, 1807, 270-274. [CrossRef] 